\title{
FREE SPEECH AND OBSCENITY LAW: TOWARD A MORAL THEORY OF THE FIRST AMENDMENT
}

\author{
David A. J. RICHaRdS $\dagger$
}

The jurisprudential inquiry into the relation of law and morals has recently taken a striking new form that promises to reinvigorate the classical inquiry in a fruitful and controversial way. In the place of the traditional inquiry into the necessary logical relations between concepts of law, or legal systems, and substantive moral values, this new approach starts from the premise that in America written state and federal constitutions literally incorporate substantive moral criteria. Thus recent commentary gives voice to the deep intellectual need for a satisfactory fusion of constitutional law and moral theory in the absence of which "[c]onstitutional law can make no genuine advance." 1 Concurrently, it is natural to apply moral theory to the analysis of particular constitutional provisions. The relation between morality and constitutional law is not, obviously, an exact one. ${ }^{2}$ Nonetheless, certain provisions of the Constitution, such as the equal protection clause of the fourteenth amendment, crucially implicate moral ideas so that the analysis of the moral idea fundamentally illuminates the interpretation of the constitutional provision. ${ }^{3}$

† Associate Professor of Law, Fordham University; Visiting Associate Professor of Philosophy, Barnard College. A.B. 1966, Harvard University; D. Phil. 1970, Oxford University; J.D. 1971, Harvard University. Member, New York bar.

Copyright ${ }^{\circ}$ by David A. J. Richards.

This Article was written under the sponsorship of The Austinian Society, Inc., on a grant to the Society from the Rockefeller Foundation for a research project in law and philosophy. Research took place at the Center for the Study of Law and Society, Berkeley, California, and the Institute for Sex Research, Inc., Bloomington, Indiana. The author must express his gratitude to the good friends who actively assisted his research, including Diane Richards, David Leng, and Donald Levy. This paper has profited from the criticisms of Joel Feinberg, Karlynn Hinman, Paul M. Shupack, John Bruce Moore, Richard B. Parker, Stanley Paulson, Peter C. Williams, Kenneth I. Winston, and John Searle.

${ }^{1}$ Dworkin, The Jurisprudence of Richard Nixon, THE NEW YoRK Review of Books, May 4, 1972, at 35. See also Dworkin, Legal Research, DaEdalus, Spring, 1973, at 63.

2 See Richards, Equal Opportunity and School Financing: Towards a Moral Theory of Constitutional Adjudication, 41 U. CHI. L. Rev. 32, 32-33, 39-4l (1973).

${ }^{3}$ For a statement of this analysis, see Richards, supra note 2. 
Consistent with this general enterprise, this Article endeavors to show how moral theory may significantly clarify constitutional adjudications by focusing on the recent set of obscenity cases decided by the Supreme Court, especially Miller $v$. California ${ }^{4}$ and Paris Adult Theatre I v. Slaton. ${ }^{5}$ Miller and Paris Adult Theatre dramatically raise the question of the proper relation of moral and legal analysis in constitutional adjudication, for these cases relate to the fundamental structural interpretation of one of the most morally informed provisions of the federal Constitution, the first amendment.

Whatever the historical obscurities which surround the proposal and adoption of the first amendment, ${ }^{6}$ there is little question that the amendment was part of and gives expression to a developing moral theory regarding the equal liberties of men which had been given expression by Milton ${ }^{7}$ and Locke $^{8}$ and which was being given or was to be given expression by Rousseau ${ }^{9}$ and Kant. ${ }^{10}$ The technical legal history of free speech in England and America prior to the adoption of the first amendment obviously renders doubtful any consensus on the specific application of the amendment; ${ }^{11}$ a consensus, to the extent it existed, was one on the generalities of a political compromise that concealed future divergences of interpretation. ${ }^{12}$ In such circumstances, the explanation of underlying moral theory is a fortiori useful. But even if the legal history appeared to be definitive, it would, in fact, be seriously incomplete if it were not understood in the light of a history of evolving moral ideas to which the first amendment, like all laws, gives expression. The critical examination of these moral ideas not only helps to complete the legal history but also clarifies the deeper moral purposes which the first amend-

+413 U.S. 15 (1973).

5413 U.S. 49 (1973).

6 See L. Levy, Legacy of Suppression: Freedom of Speech and Press in Early AMERICAN History 176-309 (1960).

${ }^{7} \mathrm{~J}$. Milton, Areopagitica, in The Prose of John Milton 265-334 (1967).

${ }^{8} \mathrm{~J}$. Locke, Second Treatise, in Two Treatises of Government 285-446 (2d ed. P. Laslett ed. 1967); J. LOCKE, 6 Works (1823, reprinted 1963) [hereinafter LeTters CoNCERNING TOLERATION].

"J.-J. Rousseau, The Social Contract, in The Social Contract and Discourses (G.D.H. Cole transl. 1950).

10 Kant, Concerning the Common Saying: This May Be True in Theory, But Does Not Apply in Practice, in Society, Law, and Morality 159-72 (F. Olafson ed. 1961); I. Kant, THE Metaphysical Elements of Justice (J. Ladd ed. 1965).

$"$ See L. Levy, supra note 6, at 1-175.

${ }^{12}$ See id. 176-309. This seems to me the most plausible interpretation of the data presented by Levy. 
ment subserves and thus guides the proper direction of its interpretation.

The purpose of this Article is to explain a contractarian theory of the first amendment and to apply it to the recent obscenity cases. This moral theory is part of a developing line of thought familiar, in the work of Locke, ${ }^{13}$ to the framers of the Bill of Rights and developed as well by other philosophers. ${ }^{14}$

The examination of the constitutional law of obscenity, as established in Miller and Paris Adult Theatre, is a crucial test for this contractarian approach. These cases claim to identify a certain class of clearly communicative expressions which fail even to enter into the structure of first amendment analysis. It is important to know whether the Court's view is fundamentally consistent with the moral theory underlying the first amendment. If these difficult cases can be decisively analyzed, other cases may follow more easily.

A necessary preliminary step, however, is to examine the very notion of the obscene. The contours of the notion are not selfevident. In order to understand the law of obscenity, some precision must be given to this notion itself.

\section{The Concept of the Obscene}

In giving a satisfactory philosophical explication ${ }^{15}$ of the notion of the obscene, one wishes to provide a constructive account which will clarify the notion itself, its connections to related notions, such as the pornographic, the indecent, and the immoral, its uses in speech, and its relations to fundamental attitudes which explain how the notion comes to have moving appeal to conduct. Initially, we must describe some general marks of the obscene. Then, a constructive account of the notion will be proposed and, finally, an attempt will be made to connect the account to crucially related notions, especially the pornographic.

\section{A. The Marks of the Obscene}

The etymology of "obscene" is obscure. The Oxford English Dictionary notes that the etymology is "doubtful," 16 while Webster's suggests a derivation from the Latin $o b$, meaning "to," "be-

${ }^{13}$ See note 8 supra.

${ }^{14}$ See note 9 supra; Kant, supra note 10 , at 164 , 166-67; 1 . KANT, supra note 10 , at 58 , $72,80,111-12,119,129$.

${ }^{15}$ For an account of criteria of theoretical adequacy, see D.A.J. Richards, A THEORY OF REASONS FOR ACTIONS 3-10 (1971).

${ }^{16}$ See 7 OXford ENglish Dictionary 0.26 (1961). 
fore," "against," and the Latin caenum, meaning "filth."17 Other commentators suggest alternative derivations from the Latin obscurus, meaning "concealed," 18 or a derivation as a corruption of the Latin scena meaning "what takes place off stage."19 In the latter sense, blinding Gloucester on stage in King Lear would have been an obscenity for a Greek playwright like Sophocles (thus, Oedipus is blinded off stage), but it was not for an Elizabethan playwright like Shakespeare who was imbued with the bloodthirstiness of Senecan tragedy.

The standard dictionary definition of "obscene" turns on notions of what is offensive to decency, filthy, or disgusting. ${ }^{20}$ While contemporary legal discussions emphasize the applicability of "obscene" to depictions, it is clearly significantly applied to acts themselves. Shakespeare, for example, speaks of an obscene deed, ${ }^{21}$ and Sartre discusses obscene movements of the body. ${ }^{22}$ In the law, it is notable that the earliest English obscenity conviction was for obscene acts. ${ }^{23}$ Judicial decisions ${ }^{24}$ and legal ${ }^{25}$

${ }^{17}$ See Webster's Third New International Dictionary 1557 (1965).

${ }^{18}$ Kaplan, Obscenity as an Esthetic Category, 20 Law \& Contemp. Prob. 544, 550 (1955). For a critique of the etymology, see van den Haag, Quia Ineptum, in "To DePrave AND CoRrupt ..." 111, 119 n.2 (J. Chandos ed. 1962) [hereinafter To Deprave and Corrupt].

19 H. Ellis, On Life and Sex 175 (1962); G. Gorer, The Danger of Equality 218 (1966); Allen, The Writer and the Frontiers of Tolerance, in To DePRAve AND CoRrupt, supra note 18 , at 141,147 .

${ }^{20}$ See notes 16 \& 17 supra.

21 "O, forfend it, God, that, in a Christian climate, souls refin'd should show so heinous, black, obscene a deed!" W. ShakeSPEARE, Richard II, act IV, scene 1 . The deed in question is a subject's judging his king.

${ }^{22}$ J.P. SARTRE, Being AND Nothingness 401-02 (H. Barnes transl. 1956); $c f$. the notion of "the jest obscene," as used in Nitocris' condemnation of her son in Handel, Belshazzar, act I, scene 4 (1744).

${ }^{23}$ Sir Charles Sydlyes Case, 83 Eng. Rep. 1146 (K.B. 1663). Sir Charles Sedley was here convicted "for shewing himself naked in a balkony, and throwing down bottles (pist in) vi \& armis among the people in Covent Garden, contra pacem and to the scandal of the Government." Id. at 1146-47. Sedley's conduct was condemned for its intrinsic obscenity as well as on the four additional grounds of indecent exposure, blasphemy, throwing missiles containing urine, and inciting to the small riot that ensued. For a reconstruction of these events, see Alpert, Judicial Censorship of Obscene Literature, 52 Harv. L. REv. 40, 41-43 (1938). One commentary on these events states that Sedley also excreted in public. See A. Craig, The Banned Books of England 23-24 (1962); D. Thomas, A Long Time BURNING 81 (1969).

${ }^{24}$ Thus, the prurient interest test for obscenity, established in Roth v. United States, 354 U.S. 476, 487 (1957), and reaffirmed in Miller v. California, 413 U.S. 15, 24 (1973) and Paris Adult Theatre I v. Slaton, 413 U.S. 49 (1973), is defined in terms of "a shameful or morbid interest in nudity, sex, or excretion." See note 58 infra. See also Roth v. Goldman, 172 F.2d 788, 790 (2d Cir. 1949) (Frank, J., concurring); United States v. Kennerley, 209 F. 119, 121 (S.D.N.Y. 1931); State v. Lerner, 81 N.E.2d 282, 289, 294 (Ohio C.P. Hamilton County 1948).

2.5 See Model Penal Code \$ 207.10, Comment at 1, 10, 29-31 (Tent. Draft No. 6, 1957). 
and general ${ }^{26}$ commentary emphasize the connections of the obscene to the notion of shame. It is clear that in European thought the notion of the obscene has long been connected to the scatological ${ }^{27}$ and the sexually lascivious, ${ }^{28}$ a connection emphasized in Anglo-American legal history. ${ }^{29}$ This history also makes clear the significant relation of the obscene to the notion of the mor-

${ }^{26}$ See, e.g., Kaplan, supra note 18, at 556. See also United States v. Roth, 237 F.2d 796, 809 n.21 (2d Cir. 1956) (Frank, J., concurring), aff'd 354 U.S. 476 (1957). Cf. Rosen v. United States, 161 U.S. 29, 31 (1896).

${ }^{27}$ For example, Alexander Pope in his remarkable denunciations of Curl in The Dunciad uses "obscene" in excretory contexts. Thus, noting a pile of excrement:

Which Curl's Corinna chanc'd that morn to make: ...

Here fortun'd Curl to slide; . . .

Obscene with filth the miscreant lies bewray'd,

Fal'n in the plash his wickedness had laid ....

A. Pope, The Dunciad 299 (J. Sutherland ed. 1963) (first published 1728, 1743). Or, Curl's goddess, Cloacina, heeding his prayer to rise from feces,

List'ning delighted to the jest unclean

Of link-boys vile, and watermen obscene;

…

She oft had favour'd him, and favours yet.

Renew'd by ordure's sympathetic force, ...

Vig'rous he rises; from th'effluvia strong

Imbibes new life, and scoürs and stinks along;

Re-passes Lintot, vindicates the race,

Nor heeds the brown dishonours of his face.

Id. 300. For a discussion of the relation of Curl (the defendant in Rex v. Curl, 93 Eng. Rep. 849 (K.B. 1727) (the first case to hold obscene libel to be a common law misdemeanor)) and Pope, see A. Craig, The Banned Books of England 26-32 (1962). For an account of Rex $v$. Curl and its background, see D. THomas, supra note 23, at 78-84.

${ }^{28}$ For example, in Cavalli's characteristically lascivious opera, La Calisto (ca. 1650), Calisto's amorous approach to the goddess Diana is rejected with "Taci, lascia, tacil Qual, qual delirio osceno/ l'ingeno ti confonde?", meaning "Silence, lascivious girl!/ What, what obscene delirium/ has come over your reason?" Cavalli, La Calisto, act I, scene 1.

${ }^{29}$ For a useful general account, see Alpert, supra note 23. For accounts of English legal development, see D. Thomas, supra note 23; N. St. John-STEvas, Onscenity AND THE LAW (1956). For the best general account of earlier American development, see Lockhart \& McClure, Literature, the Law of Obscenity, and the Constitution, 38 MinN. L. REv. 295 (1954).

The case establishing the common law misdemeanor of obscene libel, Rex v. Curl, 93 Eng. Rep. 849 (K.B. 1727), involved two books, Venus in the Cloister and $A$ Treatise of the Use of Flogging in Venereal Affairs, and the Victorian censorship movement was directed largely against pornographic literature. See text accompanying notes 47-51 infra. The same is true of the Comstock movement in America.

The test for obscenity established in The Queen v. Hicklin, L.R. 3 Q.B. 360,371 (1868) was "whether the tendency of the matter charged as obscenity is to deprave and corrupt those whose minds are open to such immoral influences, and into whose hands a publication of this sort is likely to fall," was originally applied to a work thought likely to suggest "thoughts of a most impure and libidinous character." Id. The Hicklin test was followed in America, set, e.g., United States v. Bennett, 24 F. Cas. 1093 (No. 14,571) (C.C.S.D.N.Y. 1879); People v. Muller, 96 N.Y. 408 (1884), until abandoned in United States v. One Book Entitled "Ulysses", 72 F.2d 705 (2d Cir. 1934), aff' 5 F. Supp. 182 
ally corrupting. ${ }^{30}$ Many of these connections were summarized in the language of the Comstock Act, which, in forbidding the mailing of obscene material in interstate commerce, speaks of "obscene, lewd, or lascivious ... publication[s]" and included in its prohibitions contraceptives and abortifacients or anything else "for any indecent or immoral use." 31

The most significant class of speech acts involving the notion of the obscene is that class of epithets, known as "obscenities,"32 which relate to excretory or sexual functions. Such expressions are, at least in reasonably well-educated circles, conventionalized ways of expressing attitudes of disgust and contempt which depend for their sometimes shocking and bracing effect ${ }^{33}$ on the impropriety of their use. In circles, like the army, ${ }^{34}$ where the verbal obscenities are constantly employed, their function seems quite different: there they are used not to signify extreme disgust but, rather, as a kind of manly, transgression-braving vocabulary whose use is a criterion of intimate membership in the group. Related to this is the use of obscenities among intimate friends and even as a language of love.

The verbal obscenities demonstrate not only the relation of the obscene to shock and offense, but to the anxiety-producing loss of control. On hearing or using such expressions in reasonably well-educated circles, one has the sense of a loss of control,

(S.D.N.Y. 1933). The new test turned on whether the "dominant effect" was "libidinous" 72 F.2d at 708, 707 .

For the current prurient interest test, established in Roth v. United States, 354 U.S. 476 (1957), see note 58 infra.

so See note 29 supra.

${ }^{31}$ The text of the substantive section of the Comstock Act $\S 2$, ch. 258, § 2, 17 Stat. 598, 599 (1873), as amended, 18 U.S.C. 1461 (1970) reads as follows:

$[N]$ o obscene, lewd, or lascivious book, pamphlet, picture, paper, print, or other publication of an indecent character, or any article or thing designed or intended for the prevention of conception or procuring of abortion, nor any article or thing intended or adapted for any indecent or immoral use or nature, nor any written or printed card, circular, book, pamphlet, advertisement or notice of any kind giving information, directly or indirectly, where, or how, or of whom, or by what means either of the things before mentioned may be obtained or made, nor any letter upon the envelope of which, or postal-card upon which indecent or scurrilous epithets may be written or printed, shall be carried in the mail ....

${ }^{32}$ A useful study of these words is E. Sagarin, The Anatomy of Dirty Words (1962). See also Read, An Obscenity Symbol, 9 AM. SPEECH 264 (1934).

${ }^{33}$ For an account of the force of such expressions in psychoanalysis, see S. Ferenczi, Sex in Psychoanalysis 132-53 (E. Jones transl, 1950); $c f$. Stone, On the Principal Obscene Word of the English Language, 35 INT'L J. Psycho-Anal. 30 (1954).

${ }^{34}$ See, e.g., Songs and Slanc of the British Soldier: 1914-1918, at 15 (3d ed. Brophy \& Partridge eds. 1931). 
a sudden frustration, or an explosion of pique, which may surprise the speaker as much as the listener.

In the light of these functions and marks of the verbal obscenities, one can better understand the functions of literature which employs obscene contents, for example, some works of Swift ${ }^{35}$ and Pope ${ }^{36}$ By employing contents known to be offensive to the conventional proprieties, such literature can express complex communicative intentions of bitter satire and burlesque ${ }^{3 \tau}$ in ways related to the capacity of the verbal obscenities to express disgust and contempt. Similarly, one can understand the use of the obscene in literary humor as well as in the smutty joke and obscene witticism. ${ }^{38}$ Obviously, such effects of the obscene are in some important way tied to attitudes, the existence of which accounts for these effects.

\section{B. An Explication of the Obscene}

The concept of the obscene is identical with the concept of those actions, representations, works, or states which display an exercise of bodily function, or such an exercise in certain circumstances, which constitutes an abuse of bodily function, as dictated by standards in which one has invested self-esteem, so that the supposed abuse of bodily function is an object of selfcontempt and -disgust.

On this view, the obscene is a subcategory of the objects of shame. Shame is, I believe, properly understood in terms of a fall from one's self-concept in the exercise of capacities which one desires to exercise competently. ${ }^{39}$ The objects of shame, thus, are explained by reference to the notions of personal competence and self-respect which are their bases. One feels ashamed because, for example, he has been cowardly, failing to exercise courageous self-control over fear when danger threatened. A characteristic mark of such failure is self-contempt or -disgust.

The obscene identifies a special class of the possible objects of shame which are explained by reference to certain defined

${ }^{35}$ See, e.g., J. Swift, $A$ Tale of $a$ Tub, in Gulliver's Travels and Other Writings 245, 327-29, 334-36 (L. Landa ed. 1960); J. SwiFT, A Voyage to Lilliput, in id. 3, 34-35.

${ }^{36}$ See A. Pope, supra note 27, at 299-300, 303-04, 306, 308-14.

${ }^{37}$ For similar remarks, with special attention to pornography, see D. Thomas, supra note 23, at 273-74, 313-14 (1969). See also S. Sontag, Styles of Radical Will 35-73 (1969).

${ }^{38}$ Cf. S. FreUd, Wit and Its Relation to the Unconscious, in The Basic Writings of SigMUND FREUD 631, 692-97 (A. Brill transl. \& ed. 1938).

${ }^{39}$ See D.A.J. RIChaRds, supra note 15 , at 250-67. 
notions of personal competence in the exercise of bodily functions. Thus, just as one explains to a child that it is an abuse and misuse of the function of a knife or fork to put either in his ear, so too one explains the proper exercise of bodily function. The use of the body, like the use of knives and forks, is thought to have precise and sharply defined functions and ends. ${ }^{40}$ This mode of thought, discernible in a pervasive way in primitive peoples and the most ancient cultures, ${ }^{41}$ including, significantly, ancient Judaism, ${ }^{42}$ rigidly defines certain clear proprieties of bodily function as pure or clean. By contrast, failure to so exercise bodily function is unclean, polluting, an abomination, in short, obscene. ${ }^{43}$

The obscene, thus, is a conceptual residuum of very ancient ways of thinking about human conduct. Human beings are thought of as clusters of strengths or virtues and corresponding weaknesses or vices, where virtues and vices are not conceived in narrow moral terms. ${ }^{44}$ Obscenity within this view is a kind of vice, a wasting and abuse of the natural employment of bodily functions. Hence, a culture's definition of the obscene will indicate those areas of bodily function in which the culture centrally invests its self-esteem and in which deviance provokes the deepest anxieties. For example, incompetence with respect to excretory function typically defines the frailest members of society, infants and the senile. Where frailty and declining powers are a source of anxiety, excretory impropriety is likely to be regarded as obscene. Moreover, where the sexual function is regarded as akin to the excretory function, as it easily may be, ${ }^{45}$ sexual behavior will come to share with excretory behavior condemnation as obscene.

Importantly, this explication of the obscene is intended to apply cross-culturally. ${ }^{46}$ To the extent people in different cultures take different attitudes to certain bodily functions, those cultures will take different views of those things that are obscene, though the cultures both share the concept of the ob-

\footnotetext{
40 I am grateful to Pat and Ann Parker for this observation.

41 See M. Douglas, Purity and Danger 1966).

${ }^{42}$ See id. 41-57.

${ }^{43}$ See, e.g., Leviticus 11-15, 17-18.

${ }^{44}$ See Aristotle, Nicomachean Ethics 116-251 (M. Ostwald transl. 1962).

${ }^{45}$ See notes 79 \& 80 infra \& accompanying text.

${ }^{46}$ For a similar attempt at cross-cultural definition of the obscene, see Honigman, a Cultural Theory of Obscenity, in Sexual Behavior and Personality Characteristics 31 (M. DeMartino ed. 1963).
} 
scene as abuse of bodily function. This is true over time as well. English society in the eighteenth century was apparently very tolerant of obscene literature, despite the fact that obscene libel had become a common law offense. ${ }^{47}$ But in the nineteenth century, changing moral standards gave rise to groups like the Society for the Suppression of Vice and prosecution for obscene libel increased rapidly. ${ }^{48}$ Concern over the explosion of pornographic literature ${ }^{49}$ finally received expression in the Customs Consolidation Act of $1853^{50}$ and Lord Campbell's Act of $1857 .^{51}$ A more striking example is provided by the Tahitians who do not take the Western European or American view of the competent exercise of sexual function, but they do take a rather stringent view of eating; thus for Tahitians, displays of coitus are not obscene, but displays of eating are obscene. ${ }^{52}$ For us, aside from contexts of satirical humor, ${ }^{53}$ eating conventional food would be obscene only in extreme circumstances of gluttonous self-indulgence ${ }^{54}$ or in circumstances where eating is associated with aphrodisiacal allure. ${ }^{55}$

Significantly, this explication provides and accounts for the application of "obscene" to acts as well as depictions of acts. Both acts and depictions areobscene if they display certain "unnatural" exercises of bodily function; whether by the act itself or by depiction, our anxiety is aroused when we become aware of phenomena which assault our self-esteem. It does not follow, of course, that obscene depictions are only of obscene acts. Normal heterosexual intercourse between a married couple is not typically

\footnotetext{
${ }^{47}$ Rex v. Curl, 93 Eng. Rep. 849 (K.B. 1727). See notes 27 \& 29 supra.

${ }^{48}$ See N. St. John-Stevas, supra note 29, at 29-65; D. Thomas, supra note 23, at 113-28, 179-290.

${ }^{49}$ For a literary analysis of some notable examples of Victorian pornography, see S. Marcus, The Other Victorians (1966).

so 16 \& 17 Vict., c. 107 (repealed by Customs Consol. Act of $1876,39 \& 40$ Vict., c. 36 , $\S \S 42,288)$.

5120 \& 21 Vict., c. 83 (repealed by Obscene Publications Act of 1959, 7 \& 8 Eliz. 2, c. $66, \S 3(8)$ ). For a history of the passage of this statute, see N. Sr. JoHN-STEvas, supra note 29, at 66-69; D. THOMAS, supra note 23, at 261-63.

52 See La Barre, Obscenity: An Anthropological Appraisal, 20 LAW and Contemp. Prob. $533,541-42$ (1955). Geoffrey Gorer cites the Trobriand Islanders as a people who finds public eating of solid food an obscenity. G. GoRER, supra note 19, at 218.

For a discussion of the Indian idea that eating may be polluting, see M. Douglas, supra note 41 , at $33-34$.

${ }^{53}$ The suggestion of the reversal of the roles of eating and excretion (namely, that eating would be obscene and excretion a social occasion) is the subject of one scene of hilarious social satire in Bunuel's movie, Le Fantôme de la Liberté (1974). It is significant that for us, unlike the Tahitians, this reversal is an object of deep laughter.

${ }^{54}$ E.g., the movie La Grande Bouffe (1974).

${ }^{55}$ E.g., the famous eating scene in the movie Tom Jones (1963).
} 
viewed as obscene; but a public depiction of such intercourse would, by some people, be viewed as obscene. Nonetheless, there is little question that the obscenity of an act is a sufficient condition for the obscenity of a depiction of that act. Most cases of obscene depictions fall into this category. At one time obscenity convictions were granted for the mere sympathetic discussion of homosexuality or advocacy of birth control or abortion, apart from any pornographic representation of any kind. ${ }^{56}$ The idea seems to have been that, homosexuality or birth control or abortion being obscene, any favorable discussion of them was obscene. Even today, it is clear that courts are quickest to make or affirm judgments of obscenity with respect to depictions of sexual acts such as cunnilingus, fellatio, sodomy, sadomasochism, and bestiality that are regarded as obscene in themselves. ${ }^{57}$ The view that these acts are obscene is the basis for judging their depiction to be obscene. This is, of course, wholly unsurprising because the prurient interest criterion for the constitutionally obscene ${ }^{58}$ essentially comes to "an exacerbated, morbid, or perverted interest," 59 that is, an interest which is itself regarded as abnormal and obscene.

${ }^{56}$ See H.M. Hyde, A History of Pornography 3-8 (1964); N. ST. John-Stevas, supra note 29, at 70-74, 98-103. See also note 31 supra; notes 139 \& 140 infra.

${ }^{57}$ Compare, e.g., Paris Adult Theatre I v. Slaton, 413 U.S. 49, 52 (Burger, C.J., emphasized the occurrence of "scenes of simulated fellatio, cunnilingus, and group sex intercourse") and Mishkin v. New York, 383 U.S. 502, 508 (1965) (depictions of flagellation, fetishism, and lesbianism held obscene), with Sunshine Book Co. v. Summerfield, 355 U.S. 372 (1958) (per curiam), rev'g 249 F.2d 114 (D.C. Cir. 1957), aff'g 128 F. Supp. 564 (D.D.C. 1955) (nudity per se not obscene). Cf. R. KuH, Foolish Figleaves? 306-07 (1967) (suggesting that pictured bestiality and homosexuality are more obscene than comparable pictured heterosexuality).

${ }^{58}$ In Roth v. United States, 354 U.S. 476 (1957), the Supreme Court held that material was obscene if "the average person, applying contemporary community standards, [would find that] the dominant theme of the material taken as a whole appeals to the prurient interest," $i d$. at 489 , meaning "a shameful or morbid interest in nudity, sex, or excretion, [going] substantially beyond customary limits of candor in description or representation of such matters." Id. at 487 n.20 (quoting from MODEL PENAL CODE § 207.10(2) (Tent. Draft No. 6, 1957)).

The test was restated in A Book Named "John Cleland's Memoirs of a Woman of Pleasure" v. Attorney General, 383 U.S. 413 (1966), so that the material had to be not merely prurient, but "patently offensive because it affront[ed] contemporary community standards relating to the description or representation of sexual matters . .." Id. at 418 . After Miller v. California, 413 U.S. 15 (1973), however, the test turns on "whether the work depicts or describes, in a patently offensive way, sexual conduct specifically defined by the applicable state law," $i d$. at 24 , rather than on the more nebulous "contemporary community standards."

In thus defining the obscene in terms of appeal to prurient interest, the Court has expressly excluded from the obscene other contents, such as the portrayal of violence, Winters v. New York, 333 U.S. 507 (1948) (this holding questionable today because of a growing usage applying the notion of the obscene to violence, on the analogy, in my view, 
The connection between the obscenity of acts and depictions of acts distinguishes the obscene from the indecent. The distinctive mark of the indecent is the public exhibition of that which, while unobjectionable in private, is offensive and embarrassing when done in public. ${ }^{60}$ The obscene, by contrast, may be and often is condemned whether or not it involves a public display. ${ }^{61}$

Finally, this linkage between the act and its depiction provides an account for the use of obscene contents in speech acts expressing contempt and disgust. Since the obscene identifies a disgusting abuse of bodily function, it is wholly natural that it should be used to express disgust. ${ }^{62}$ It follows that, if one does not find certain communicative contents obscene, one may tendentiously advocate the abandonment of speech acts using those contents to express disgust. ${ }^{63}$

\section{The Obscene and the Pornographic}

Pornography etymologically derives from the Greek pornographos, meaning "writing of harlots," literally, writing concerning or descriptive of prostitutes in their profession. ${ }^{64}$ Thus, the

of an abuse of proper bodily function); sacrilege, Joseph Burstyn, Inc. v. Wilson, 343 U.S. 495, 504-06 (1952); and mere vulgarity, Hannegan v. Esquire, Inc., 327 U.S. 146 (1946). See also United States v. Klaw, 350 F.2d 155, 163 (2d Cir. 1965). (A further distinction was drawn in United States v. Limehouse, 285 U.S. 424 (1932), between "filthy" matter and "obscene" matter for the purposes of deciding the scope of legislation prohibiting the mailing of "obscene" and "filthy" matter.)

The Court has also made clear that the constitutional protection is afforded so-called thematic or ideological obscenity-material that does not in itself arouse lustful thoughts, though it might persuade the recipient to engage in obscene conduct. Kingsley Int'l Pictures Corp. v. Regents, 360 U.S. 684 (1959). An illuminating commentary on Roth and Kingsley Int'l Pictures appears in Kalven, The Metaphysics of the Law of Obscenity, 1960 SuP. CT. Rev. 1. See also Lockhart \& McClure, Censorship of Obscenity: The Developing Constitutional Standards, 45 MINN. L. Rev. 5 (1960); Lockhart \& McClure, Obscenity Censorship: The Core Constitutional Issue-What Is Obscene?, 7 UTAH L. Rev. 289 (1961).

${ }^{59}$ Model. Penal Code $\S 207.10$, Comment at 29 (Tent. Draft No. 6, 1957).

${ }^{60}$ See Feinberg, "Harmless Immoralities" and Offensive Nuisances, in IssuEs IN LAW AND Morality 83, 87 (N. Care \& T. Trelogan eds. 1973).

${ }^{61}$ The confusion of the obscene and the indecent is not uncommon. See, e.g., L. Strachey, Will It Come Right in the End?, in The Really Interesting Question 71 (1974); Art and Indecency, in id. 82.

${ }_{62}$ Expressed more formally, the view here proposed is that sentences of the form " $x$ is obscene" express true or false propositions about x's being an abuse of bodily function; this propositional content in turn explains the ground for using such an expression in various speech acts, including expressions of disgust. For a development of this kind of analysis in extenso, see D.A.J. Richards, supra note 15, at 49-62, 212-41.

${ }_{63}$ This proposal has in fact been made with respect to sexual contents. See, e.g., E. Sagarin, supra note 32, at 9-12, 160-74. Lenny Bruce, according to the show The World of Lenny Bruce, scene 1 (1974), predicted the day when, pursuant to his view of the nonobscenity of sex, the erstwhile sexual obscenities would be used as forms of congratulation and good wishes.

${ }^{64}$ See, e.g., Webster's Third New International Dictionary 1767 (1966). 
depictions of various forms of sexual intercourse on the walls of a certain building in Pompeii, intended as aphrodisiacs for the orgiastic bacchanales housed there, ${ }^{65}$ were literally pornographos. Pornography in this sense is identified by its sexually explicit content, its depiction of varied forms of sexual intercourse, turgid genitalia, and so on. ${ }^{66}$

Pornography is neither conceptually nor factually identical with the obscene. Conceptually, the notion of sexually explicit, aphrodisiacal depictions is not the same idea as that of the improper abuse of a bodily function. Factually, many cultures, though sharing in the fundamental concept of the obscene, do not regard pornography as obscene. ${ }^{67}$ Individuals within our culture may find coprophagy (eating feces) obscene, ${ }^{68}$ but do not find pornography obscene, ${ }^{69}$ because they fail to take a certain attitude toward "proper" sexual function although they do have ideas about "proper" excretory function. For such people, viewing sex or depictions of sex as obscene is an unfortunate conflation of the sexual and the excrementitious. ${ }^{70}$

${ }^{65}$ See H.M. HydE, supra note 56, at $1,10$.

${ }^{68}$ Morse Peckham suggests a procedural definition of pornography in terms of the depiction of "human sexual organs in a condition of stimulation." M. PECKHAM, ART AND PORNOGRAPHY 46-47 (1969). This definition is not implausible if one is seeking a kind of bare minimum for the pornographic, for it is clear that a depiction of a person, completely clothed except for exposure of the genitalia, would be regarded as pornographic.

See also A. Kinsey, Sexual Behavior in the Human Female 671-72 (1953); E. Kronhausen \& P. Kronhausen, Pornography and the Law 262, 265 (1959); Eliasberg, Psychiatric Viewpoints on Indecency, Obscenity, and Pornography in Literature and the Arts, 16 AM. J. Psychotherapy 477-83 (1962); Eliasberg, Art: Immoral or Immortal, 45 J. CRIM. L.C. \& P.S. 274-78 (1954); Reed, Consensus and Dissensus in Pornography Definitions, 5 INT'L BEHAVIORAL ScIENTIST 1-12 (1973). The aphrodisiacal functions of pornography are shown by the fact that popular sex manuals recommend it in certain circumstances. See, e.g., THE JoY of Sex 208-09 (A. Comfort ed. 1972).

${ }^{67}$ See H.M. Hyde, supra note 56, at 30-58; D. Loth, The Erotic in Literature 41-68 (1961); M. Рескнам, supra note 66, at 257-301; La Barre, supra note 52, at 533-35. See also L. Gichner, Erotic Aspects of Chinese Culture (1957); L. Gichner, Erotic Aspects of Japanese Culture (1953); P. Rawson, Erotic Art of the East (1968).

${ }^{68}$ The example of coprophagy occurs in M. DE SADE, 120 Days of Sodom, in $2 \mathrm{~T}_{\mathrm{HE}}$ Complete Marquis de SAde 215, 222 (P. Gillette transl. 1966). De Sade provides other similar examples, such as eating vomit, which someone might find obscene, even if he would not find pornography obscene. Id. 215.

${ }^{69}$ See R. HANey, Comstockery in America 58-9, 67-69, 75 (1960); D. Loth, supra note 67, at 208-33; L. Marcuse, Obscene: The History of an Indignation 303-27 (K. Gershon transl. 1965); M. Peckham, supra note 66, at 19-20, 46; B. Russell, Marriage AND Morals 93-117 (1929); E. SAGARIN, supra note 32, at 9-12, 160-74. But cf. Goodman, Pornography, Ait, and Censorship, in Perspectives on Pornography 42 (D. Hughes ed. 1970); Sagarin, On Obscenity and Pornography, in The New Sexual Revolution 105 (L. Kirkendall \& R. Whitehurst 1971).

${ }^{70}$ See H. Ellis, supra note 19, at 21-37; E. Kronhausen \& P. Kronhausen, supra note 66 , at 167; B. RusselL, supra note 69; at 106-07. 
If there is no necessary connection between the pornographic and the obscene, how did the connection between them arise?

One account of the sexual morality behind this connection is that of Catholic canon law which

holds, as a basic and cardinal fact, that complete sexual activity and pleasure is licit and moral only in a naturally completed act in valid marriage. All acts which, of their psychological and physical nature, are designed to be preparatory to the complete act, take their licitness and their morality from the complete act. If, therefore, they are entirely divorced from the complete act, they are distorted, warped, meaningless, and hence immoral. ${ }^{71}$

This view of course derives from St. Augustine's classic conception that the only proper "genital commotion"72 is one with the voluntary aim of reproduction of the species. ${ }^{73}$ It follows from this view that only certain rigidly defined kinds of "natural" intercourse in conventional marriage are moral; "unnatural" forms of such intercourse are forbidden; extramarital and of course homosexual intercourse is forbidden. Further, all material that will induce to "genital commotion" not within marriage is forbidden. Pornography is obscene not only in itself, because it displays intercourse not within marriage, but also because it tempts to intercourse outside marriage or to masturbation, which are independently obscene acts because they are forms of sexual conduct that violate minimum standards of proper bodily function and thus cause disgust.

While this specific Catholic view is not the universal basis for the connection of the obscene and the pornographic, this general kind of view seems always present. Sexual function of certain rigidly defined kinds is alone the correct and competent exercise of sexual function. All other forms are marked by failure, weak-

${ }^{11}$ Gardiner, Moral Principles Toward a Definition of the Obscene, 20 LAw \& ConTEMP. Prob. 560, 564 (1955); $c f$. T.L. Bouscaren, A. Elus \& F. Korth, Canon Law 711-33 (1946). For similar statements of the Catholic view, see H. Gardiner, Catholic VIewPOINT ON CENSORShIP 62-67 (1958); T. MURPhy, CENSORSHIP: GovernMENT AND OSCENITY 34-36 (1963). For a critique, see R. HANEY, supra note 69 , at 88-96.

${ }^{72}$ This quaint phrase appears in GARDINER, supra note 71, at 567.

${ }^{73}$ See, Augustine, The City of God 470-72 (M. Dods transl. 1950). St. Thomas Aquinas is in accord with Augustine's view. Of the emission of semen apart from generation in marriage, he wrote, "after the sin of homicide whereby a human nature already in existence is destroyed, this type of sin appears to take next place, for by it the generation of human nature is precluded." T. Aquinas, ON THE TRUTH OF THE CATHOLIC Faith: Summa Contra Gentriles 146 (V. Bourke transl. 1946). But of. W. Masters \& V. Johnson, Human SeXUal. INADEQUaCY 198-99 (1970) (insisting that sexuality cannot be willed). 
ness, and disgust. Masturbation in particular is a moral wrong. ${ }^{74}$ Clearly this general notion, premised on supposed medical as well as theological facts, was behind the extraordinary explosion in obscenity legislation in England and the United States in the 1850's, 1860's, and 1870's. ${ }^{75}$ In particular, this legislation rested squarely on the remarkable Victorian medical view relating masturbation and sexual excess in general to insanity. ${ }^{76}$ Pornography, being in part masturbation fantasy, ${ }^{77}$ was condemned on medical as well as theological grounds, so that Anthony Comstock, the father of the Comstock Act, could point with the support of medical authority to the fact that pornoggraphy's "most deadly effects are felt by the victims in the habit of secret vices. ..."78

Significantly, Victorian medical literature and pornography ${ }^{79}$ make transparent that sexual function was construed on the model of excretory function. ${ }^{80}$ The proper exercise of sexual function was rigidly defined in terms of one mode, marital re-

${ }^{74}$ Accordingly, statutes have made it a crime to allure minors to commit masturbation. See, e.g., Ind. AnN. STAT. \& 10-4221 (Supp. 1974).

75 Prior to that time, obscenity had only reluctantly been accepted into the common law. See sources collected at note 29 supra. Indeed, originally, obscenity had been regarded as objectionable only in connection with blasphemy and thus best left to the ecclesiastical courts. The Queen v. Reed, 92 Eng. Rep. 777 (K.B. 1708). Thus, the Catholic Church had allowed the Decameron to be published, leaving in the sexually explicit material but changing the nuns and priests involved to other kinds of persons. See N. ST. JoHNStevas, supra note 29, at 4-5. See also St. John-Stevas, The Church and Censorship, in To DePrave AND CoRrupr, supra note 18 , at 89.

${ }^{76}$ See A. Comfort, The Anxiety Makers (1970); J. Haller \& R. Haller, The Physician and Sexuality in Victorian America 191-234 (1974); S. Marcus, supra note 49; Hare, Masturbational Insanity: The History of an Idea, $108 \mathrm{~J}$. Mental ScIENCE 1, 6-9 (1962). Thus, one standard Victorian work on sexual function observes that, as a consequence of masturbation, a boy becomes "sluggish and enfeebled, and if his evil habits are persisted in, he may end in becoming a drivelling idiot or peevish valetudinarian", excerpt quoted in S. MARcus, supra note 49, at 19; $c f$. excerpt quoted in A. COMFORT, supra 107-08.

${ }^{77} \mathrm{Cf}$. Allen, supra note 19 , at 144 .

${ }^{78}$ A. Comstock, TRAPS FOR THE Young 136 (R. Bremner ed. 1967). See also id. 132-33, 139, 145, 169, 179, 205; A. CoMstock, Frauds EXPosed 388-389, 416, 437-38, 440-41 (1880, reprinted 1969).

${ }^{79}$ See, e.g., S. MARCUS, supra note 49, at 24-25, 233, 243.

${ }^{80}$ See H. ElLrs, supra note 19, at 21-25. In this connection, Masters and Johnson observe:

Seemingly, many cultures and certainly many religions have risen and fallen on their interpretation or misinterpretation of one basic physiological fact. Sexual functioning is a natural physiological process, yet it has a unique facility that no other natural physiological process, such as respiratory, bladder, or bowel function, can imitate. Sexual responsivity can be delayed indefinitely or functionally denied for a lifetime. No other basic physiological process can claim such malleability of physical expression.

W. MASTERS \& V. JoHNSON, supra note 73, at 10. 
productive sexuality. Within that mode, the proper function was one of regularity and moderation. Thus, doctors condemned sexual excess within marriage ${ }^{81}$ and deprecated infertile sexual activity within marriage as "conjugal onanism." 82 This rigid and narrow conception of sexual function was obviously profoundly opposed to pornography which would expose, in the words of one prominent Victorian court, "the minds of those hitherto pure ... to the danger of contamination and pollution from the impurity it contains." 83

Similar views regarding the evils of masturbation are echoed in contemporary writers who condemn pornography. Thus, D. $H$. Lawrence emphasized the corrosive effects of autoeroticism on the capacity for the central spiritual experience, for Lawrence, of sexual mutuality between partners. ${ }^{84}$

Whatever the form of theological, medical, or psychological belief underlying the association of the obscene and the pornographic, some such belief always obtains, so that there is a significant correlation between judgments of obscenity and the judgments that a certain work is both sexually arousing and quite unpleasant. ${ }^{85}$

\section{The Moral Theory of the First Amendment}

Having attempted to clarify the notion of the obscene which underlies obscenity law, we must now elaborate the suggestion that a certain developing contractarian moral theory may significantly clarify the moral basis and proper interpretation of the first amendment. First, we will focus on the moral principles centrally relevant to this problem, namely, the principles of justice. Then, we will be able to apply these principles to the moral analysis of the constitutional interpretation of the first amendment.

\section{A. The Principles of Justice}

An adequate moral theory would express the intuitive features of the common sense notion of morality, organizing these

${ }^{81}$ A. Comfort, supra note 76 , at 57.

${ }^{82}$ Id. $155,161$.

${ }^{83}$ The Queen v. Hicklin, L.R. 3 Q.B. 359,372 (1868).

${ }^{84}$ See D.H. Lawrence, Sex, Literature, and Censorship 64-81 (1953). For similar sentiments see Mead, Sex and Censorship in Contemporary Society, in New WorLd Writing, 7, 19-21 (1953).

${ }^{85}$ See United States Comm'n on Obscenity and Pornography, Report of the COMm'N ON OBSCENITy and PORNOGRAPHy 210-12 (GPO ed. 1970) [hereinafter ReporT]; 
features in a constructive and determinate way. The central intuitive features of morality are mutual respect ${ }^{86}$ - treating others as you would like to be treated in comparable circumstances; universalization $^{87}$-judging the morality of principles by the consequences of their universal application; and minimization of fortuitous human differences, like clan, caste, ethnicity, and color, as a basis for differential treatment. 88

This Article employs a contractarian analysis, following the model of John Rawls, ${ }^{89}$ that incorporates the intuitive features of morality in this way: Moral principles are those that perfectly rational men, irrespective of historical or personal age, in a hypothetical position of equal liberty and having all knowledge and reasonable belief except that of their specific personal situation, would agree to as the ultimate standards of conduct that are applicable at large. Mutual respect is inherent in the idea of moral principles as standards to which all men would consent, defining the ways in which they, as well as others, should be treated in comparable circumstances. Universalization is expressed by the idea that the morality of any principle is to be judged on the assumption that it is generally accepted and acted on. The minimization of fortuity is guaranteed by the ignorance of specific identity.

Our concern is to apply this definition of moral principles to a theory of justice, so we must introduce into the original position the existence of conflicting claims over a limited supply of "general goods" and consider a specific set of principles to regulate claims on such goods. If there were general goods in abundant superfluity, or if people were more willing to sacrifice their interests for the good of others, the need for principles of justice might be nonexistent or significantly different. ${ }^{90}$

cf. Higgins \& Katzman, Determinants in the Judgment of Obscenity, 125 Am. J. Psychiat. 1733 (1969).

${ }^{86}$ See K. Baier, The Moral Point of View 187-213 (1958); D. Gauthier, Practical Reasoning 81-94 (1963); G. Grice, The Grounds of Moral Judgment (1967); J. Rawls, A THeORY OF JUSTICE 130-32 (1971); D.A.J. Richards, supra note 15, at 75-91.

${ }^{87}$ See R.M. HARE, FreEdom and ReAson 92-94 (1963); D.A.J. Richards, supra note 15 , at $83-85,216$.

${ }^{88}$ This idea is the basis of Kant's theory of autonomy. See I. Kant, Foundations of THE Metaphysics of MoRALs 65-71 (L. Beck transl. 1959). Cf. J.S. Mill's remark that the true idea of distributive justice consists in "redressing the inequalities and wrongs of nature." J.S. Mill, 2 Principles of Political Economy 398 (1864). Mill thus concludes that primogeniture is unjust in that distinctions are grounded on accident. Id. 505. Cf. Sidgwick's claim that justice rewards voluntary effort not natural ability alone. H. SIDGwick, The Principles of Political Economy 505-06, 531 (1887).

${ }^{89} \mathrm{~J}$. RAwLs, supra note 86; D.A.J. Richards, supra note 15, at 75-91.

${ }^{90}$ For David Hume's remarkable discussion of the conditions of moderate scarcity, see D. Hume, a Treatise of Human Nature 485, 495 (1888). 
"General goods" are those things or conditions that are typically the objects of rational choices or desires as the generalized means to a variety of particular desires. ${ }^{91}$ It is natural to classify liberty as one of these general goods. Liberty for $A$ to do X implies the absence of constraint, either to do or not to do X; obviously, the existence of various rights and liberties is an important generalized means enabling each person to pursue his particular ends, whatever they may be. Liberties of thought and expression (freedom of speech, the press, religion, and association), civic rights (impartial administration of civil and criminal law in defense of property and person), political rights (the right to vote and participate in political constitutions), and freedom of physical, economic, and social movement are fundamental in this respect. Similarly, it is natural to identify opportunity, ${ }^{92}$ capacity, property, and wealth as basic distributive goods.

The original position presents a problem of rational choice under uncertainty: rational men in the original position have no way of predicting the probabilities that they may end up in any given situation of life. If a person agrees to principles of justice that permit deprivations of liberty and property rights and later discovers that he occupies a disadvantaged position, he will have no just claim against deprivations which may render his entire life prospects meager and bitterly servile. To forestall such consequences, the rational strategy in choosing the basic principles of justice would be the conservative "maximin" strategy:93 make certain that the worst position in the system adopted is the best of all conceivable worst positions, that is, maximize the minimum condition. Thus, if a person is born into the worst possible situation of life allowed by the adopted moral principles, he or she will still be better off than in the worst situation allowed by any other possible principles.

The application of the maximin strategy requires us to consider the interpretation and relative weight assigned the general goods by those in the original position. These dimensions will crucially determine the principles governing the distribution of general goods.

Consider, for example, the liberties of thought and expres-

91 The notion of rationality considered here is developed in D.A.J. RICHARDS, supra note 15, at 27-48, 63-71. See also C. Fried, AN ANatomy of Values 87-101 (1970); J. RAwLs, supra note 86, at 407-16. The general view of the good is discussed in id. 395452; D.A.J. RichaRDS, supra note 15, at 286-91.

${ }^{92}$ See Richards, supra note 2, at 41-49.

${ }^{93}$ See J. RawLs, supra note 86 , at 150-61. 
sion, in speech, the press, religion or association. The idea here is that people are not to be constrained to communicate or not to communicate, to believe or not to believe, to associate or not to associate. The value placed on this cluster of ideas derives from the notion of self-respect ${ }^{94}$ that comes from a mature person's full and untrammelled exercise of capacities central to human rationality. ${ }^{95}$ Thus, the significance of free expression rests on the central human capacity to create and express symbolic systems, such as speech, writing, pictures, and music, intended to communicate in determinate, complex and subtle ways. Freedom of expression permits and encourages the exercise of these capacities: it supports a mature individual's sovereign autonomy in deciding how to communicate with others; it disfavors restrictions on communication imposed for the sake of the distorting rigidities of the orthodox and the established. In so doing, it nurtures and sustains the self-respect of the mature person.

Further, freedom of expression protects the interest of the mature individual, with developed capacities of rational choice, in deciding whether to be an audience to a communication and in weighing the communication according to his own rational vision of life. ${ }^{96}$ This idea was expressed by Kant by the moving thought that each rational being is a sovereign legislator in the realm of ends. ${ }^{97}$ It is a contempt of human rationality for any other putative sovereign, democratic or otherwise, to decide to what communications mature people can be exposed.

The value of free expression, in this view, rests on its deep relation to self-respect arising from autonomous self-determination without which the life of the spirit is meager and slavish. ${ }^{98}$ Other arguments for the moral value of free expression, for example, its relation to the discovery of truth, ${ }^{99}$ seem, by contrast, less powerful and often unhappily overused when they will not bear the fundamental weight they are expected to support. ${ }^{100}$

${ }^{94}$ Self-respect has its natural basis in our desire to exercise our capacities competently. See D.A.J. RichaRds, supra note 15, at 257, 267-68.

${ }^{95}$ See note 91 supra. See also J. Bennetr, Rationality (1964).

${ }^{96} \mathrm{Cf}$. Scanlon, $A$ Theory of Freedom of Expression, 1 Philos. \& Pub. Afrairs 204 (1972).

${ }^{97}$ See, e.g., I. KANT, supra note 88 at 50 et seq.

${ }^{98}$ Cf. J.S. Mill, ON LiberTy 67-90 (C. Shields ed. 1956). See also C. Bay, The StrucTURE OF FREEDOM 65-152 (1965).

${ }^{99}$ Curiously, Mill emphasizes these arguments when he discusses the moral basis for freedom of thought and discussion, J.S. MiLl, supra note 98, at 19-67, yet, stronger arguments are mustered when he discusses individuality, id. 67-90. Cf. C. REMBAR, THE END OF OBSCENITY 12-13 (1968).

${ }^{100}$ It is difficult to see why a general system of equal liberty is necessarily the best system to advance the cause of truth. On this ground alone, it would seem that a better 
Such arguments, to the extent they are valid, at best provide additional reasons to value freedom of communication. The value of free expression is, however, as strong as its best moral argument, which is more potent than many another political banality now used in its defense. ${ }^{101}$

One can clarify the nature and weight of other liberties in similar ways. Voting rights importantly confirm a person's sense of autonomous self-direction, without which the spirit shrivels into apathy. Access to the criminal and civil law affords basic security of the person. The liberty of physical, social, and economic movement frees a person from the fortuitous place and class of his birth, thereby granting effort and aspiration open horizons. In short, all these liberties, like the liberties of expression, nurture a basic sense of self-respect, a belief in the competent independence and integrity of one's person.

Similarly, basic opportunities are important preconditions to the realization of the full value of equal liberties. Voting is often a plebiscitary sham in a society whose population, lacking educational opportunity, is largely illiterate. Without the training that forms an independent intellectual conscience, freedom of thought may be an ingredient of ochlocracy. Legal freedom of social and economic movement is without value if institutions do not provide the training that makes such movement possible in fact.

Because such liberties and basic opportunities are among the fundamental factors that shape a person's capacity to become a full rational being and to enjoy the life of such a being, the rational contractors of the model of political morality could not, consistently with the maximin strategy of rational choice, agree to any configuration of principles except the one providing equality in the distribution of each of these general goods. The maximin strategy calls for institutions that afford the most disadvantaged people a higher rational expectation of desire satisfaction than any alternative system would afford them. Use of the maximin strategy in choosing principles relating to liberty and basic

system would be to limit equal liberty to very narrow technocratically defined groups. Further, the fact that a person chooses to believe and espouse views widely known to be absurdly false does not diminish his moral right to express those views, notwithstanding that he thereby advances falsity. This shows not that free expression is not worth defending, but that the value of free expression stands on grounds independent of the argument of advancing truth.

101 Cf. J. Rawis, supra note 86, at 209-11. 
opportunity, then, tends to eliminate the disadvantaged class; the highest lowest condition is equality for all persons.

By contrast, once a certain minimum level of property and income is guaranteed, the rational interest in property and income is not as fundamental as that in liberty and basic opportunity. ${ }^{102}$ Assuming the greatest amount of equal liberty and basic opportunity for all, ${ }^{103}$ inequalities in property and income above the minimum are tolerable if there are countervailing advantages. A relatively poor person, with full liberty and basic opportunity, may be better off in a system that allows inequalities in the distribution of wealth than in a system that requires equality: the consequences of inequality, for example, incentive effects on total production, may increase his absolute well-being although his relative share is less than it would be in a system with mandated equality of wealth.

The following principles of justice regulating the distributive shares of general goods would therefore be accepted in the original position: ${ }^{104}$

The principle of equal liberty and basic opportunity. Basic institutions are to be arranged so that every person in the institution is guaranteed the greatest equal liberty and basic opportunity compatible with a like liberty and basic opportunity for all.

The principle of justified inequality. Inequalities in the distribution by institutions of general goods like money, property, and status are to be allowed only if those inequalities are a necessary incentive to elicit the exercise of superior capacities, and only if the exercise of those capacities advances the interests of typical people in all standard classes in the institution more than equality would advance those interests and makes the life expectation of desire satisfaction of the typical person in the least advantaged class as high as possible.

In considering the derivation of these principles from the formal model, it is illuminating to bear in mind the special importance of the formal assumption of the contractors' ignorance of

${ }^{102}$ I put aside for present purposes the question of capacity distribution. For a discussion of this point, see D.A.J. RICHARDS, supra note 15, at 135-38.

${ }^{103}$ Including the liberty and opportunity to hold and dispose of personal property. Obviously, this does not prejudge the morality of the private or public ownership of the basic means of production.

104 This formulation is based on D.A.J. RIchards, supra note 15, at 121. For Rawls' formulation, see J. RAwLS, supra note 86 , at 302-03. 
their particular desires, nature, and circumstances. Thus, the derivation of free expression is made possible by the contractors' ignorance of their specific beliefs and tastes. Consequently, there can be no appeals to special religious duties to a Catholic or Muslim or Jewish God that override the equal liberty of religious belief; nor can there be appeals to any taste or distaste for certain kinds of literature in order to override the equal liberty of free speech and press. Not knowing which, if any, is their religion or taste in literature, the contractors' reasoning in the original position will be based on ordinary principles of empirical inference and the knowledge which such principles yield, not on special kinds of principles and knowledge which religious faith or taste may involve. ${ }^{105}$ It follows, of course, that moral arguments, qua moral, regarding the proper application of the principle of equal liberty must rest on general empirical views; arguments based on special perceptions that would not be admissible in the original position must be decisively rejected.

In applying the equal liberty principle, the basic liberties must be assessed as an interrelated system. The weights of each kind of liberty may depend on the specification of other kinds of liberty. ${ }^{106}$ With respect to the liberties of expression, we have observed that these liberties constitute both a right to communicate and a right to be the object of communication. Obviously, these liberties must be adjusted to one another in such a way as to best realize the underlying values of autonomous self-determination. The morally preferable adjustment is a liberty to communicate to any audience that is itself at liberty to choose to be or not to be an audience. Given this interpretation, the liberty to communicate, and other liberties are to be assessed as a whole in the light of the principle requiring the greatest equal liberty compatible with a like liberty for all.

\section{B. Justice and the First Amendment}

Having formulated the relation between the principles of justice and the allocation of general goods, we must now apply the formulation to clarify the proper constitutional standards for legislation bearing on the distribution of these goods. This is part of the general problem of just constitutional design. The rational contractors in the original position would, of course, know the general characteristics of their land: its resources and stage of 
economic growth, the extent of literacy, and other relevant conditions. They would not know their own identity, however. On the basis of such facts and within the constraints established by the principles of justice, the rational contractors must agree on a general constitutional framework.

It is unlikely that there is a unique solution to the problem of just constitutional design; rather, any one of a range of constitutions, involving different institutional frameworks, might be adopted. A constitution providing that certain fundamental civil and human rights are to remain intact, notwithstanding the wishes of legislative majorities or popular leaders is certainly coherent with the idea of minimal principles of justice suggested above. Indeed, as suggested earlier, ${ }^{107}$ it is historically plausible that the first amendment is an early expression of a developing contractarian theory of justice. The moral foundation of constitutional democracy is not majority rule, but the principles of justice. Majority rule is only justified to the extent that it coheres with the principles of justice. ${ }^{108}$ Thus, the utilitarian political calculations of majority rule are limited by substantive benchmarks of justice; there are points beyond which the interests of the few may not be sacrificed to advance interests of the many. ${ }^{109}$ Whatever its historic origins, the spirit and explicit content of the first amendment is, of course, at one with contractarian moral theory: freedom of speech, and of the press, and religious liberty are not to be abridged, popular wishes to the contrary notwithstanding. ${ }^{110}$

In interpreting and enforcing the first amendment, courts must determine, as a matter of progressively unfolding constitutional interpretation, the proper standards under which their responsibility is to be discharged. On the basis of our formulation of applicable principles of justice the constitutional notions of free speech and free press should be understood in terms of

${ }^{107}$ See text accompanying notes 6-14, supra.

${ }^{108}$ It follows that criticisms of constitutional adjudication, premissed on its frustration of majority rule, rest on a superficial analysis of the moral principles underlying constitutional democracy. For notable examples of such criticisms, see Thayer, The Origin and Scope of the American Doctrine of Constitutional Law, 7 HARv. L. REv. 129 (1893); L. HAND, The Bill of Rights (1968).

${ }^{109}$ Cf. D.A.J. Richards, supra note 15 , at 87.

110 "Congress shall make no law respecting an establishment of religion, or prohibiting the free exercise thereof; or abridging the freedom of speech, or of the press; or the right of the people peaceably to assemble, and to petition the Government for a redress of grievances." U.S. Consr. amend. I. J.S. Mill stated the underlying moral point dramatically when he wrote: "If all mankind minus one were of one opinion, mankind would be no more justified in silencing that one person than he, if he had the power, would be justified in silencing mankind." J.S. MILL, supra note 98, at 21. 
the relevant requirements of the first principle of justice, namely, the greatest equal liberty of communication compatible with a like liberty for all. Thus, all legal prohibitions and regulations which constrain liberty of communication in a manner incompatible with this idea should be constitutionally forbidden and invalid.

The institutions and practices of free expression must be assessed as a system ${ }^{111}$ with a view to ascertaining whether they violate or cohere with the idea of a system of greatest equal liberty compatible with a like liberty for all. For example, it is clear that procedural rules of order, time, and place which regulate a reasonable pattern of communications, cohere with this idea, for they enlarge the equal liberty of communication compatible with a like liberty for all. ${ }^{112}$ Without such rules of order, time, and place, the liberty of communication of one will be used to violate the liberty of communication of another so that the system of liberties is not the greatest equal liberty compatible with a like liberty for all.

Similarly, the punishment of communications that are an indispensable part of actions concretely designed and imminently and realistically capable of effectuating the overthrow of the constitutional order-for example, communicating military secrets to the enemy-does not violate this equal liberty of communications, for such communications would help to overthrow the system of equal liberties. The proof that such communications do advance the overthrow of the constitutional order must, however, appeal to general principles of empirical induction and inference. No special principles of inference, not admissible in deciding on the principles of justice, are admissible in the interpretation of those principles. ${ }^{113}$ Thus, special a priori views regarding the relation of certain communications to the decline and fall of the constitutional order, not justified on generally acceptable empirical grounds, are not morally tolerable as reasons for limiting such communications. ${ }^{114}$

111 I take the notion of a system of free expression from T. EMERSON, THE System OF FREEDOM OF EXPRESSION (1970).

112 See A. Meiklejohn, Political Freedom 21-28 (1960).

${ }^{113}$ See note 105 \& accompanying text supra. Cf. J. RAwLS, supra note 86, at 211-21.

${ }^{114}$ Milton would not permit free speech for "Popery and open superstition which as it extirpats all religion and civill supremacies, so it self should be extirpat . . ..." J. Milton, supra note 7, at 330. Locke excepted atheists and Catholics from his principles of toleration. LetTers Concerning Toleration, supra note 8, at 45-47. Both Milton and Locke, who thought that the beliefs of atheists and Catholics would destroy the civil order, refused to extend liberty of speech and thought to them. In their view, morality rested on religion, and therefore atheists were incapable of moral conduct which underlay the stable civil order. Roman Catholics were committed to a foreign political order dedicated to the 
Attempts by the state to prohibit certain contents of communication per se are fundamentally incompatible with the moral and constitutional principle of equal liberty. Notwithstanding the detestation of and outrage felt by the majority toward certain contents of communication, the equal liberty principle absolutely forbids the prohibition of such communications on the ground of such detestation and outrage alone. Otherwise, the liberty of expression, instead of the vigorous and potent defense of individual autonomy that it is, would be a pitifully meager permission allowing people to communicate only in ways to which no one has any serious objection. The interest of the few in free expression is not to be sacrificed on such grounds to the interest of the many, notwithstanding utilitarian calculations to the contrary. Conventional attitudes are not to be the procrustean measure of the exercise of human expressive and judgmental competence.

On this view, the constitutionally protected liberty of free expression is the legal embodiment of a moral principle which ensures to each person the maximum equal liberty of communication compatible with a like liberty for all. Importantly, if the first amendment freedoms rest on a fundamental moral principle, they have no necessary justificatory relation to the liberty of equal voting rights. No doubt, the existence of equal voting rights advances values of self-direction and autonomy that are also advanced by the liberties of expression and thought. But a maximum equal liberty of self-expression is neither a necessary nor a sufficient logical or factual condition of democratic voting rights or of the competent exercise of those rights. Voting rights may exist and be competently exercised in a regime where expression is not in general free, but is limited to a small class of talented technicians who circulate relevant data on policy issues to the electorate. Similarly, free expression may exist in a political aristocracy or in a democracy where voting rights are not competently exercised because of illiteracy or political apathy.

The independent status of the value of free expression from the value of voting rights shows not that free expression is not valuable, but that its value is not intrinsically political. It rests, rather, on deeper moral premises regarding the general exercise of autonomous expressive and judgmental capacity and the good that this affords in human life. It follows that the attempt to limit

overthrow of the existing order; therefore, tolerance of their views would cause the instability and breakdown of that order. Were these beliefs demonstrably false, as they are, presumably Milton and Locke would extend equal liberty to these groups. 
the constitutional protection of free expression to the political ${ }^{115}$ must be rejected on moral and constitutional grounds. ${ }^{116}$

Obviously, moral ideas do not coincide exactly with the first amendment. Thus, the first amendment incorporates a state action requirement. There is no moral reason why the Constitution should limit the moral right of free expression to abridgements by the state when it is equally immoral for private persons to abridge this right, ${ }^{117}$ but we must accept as a fact that law and morality do not coincide even in the first amendment.

Nonetheless, it is clear that strong moral ideas are implicit in the first amendment and that moral analysis may clarify the proper constitutional interpretation and application of those ideas. It is significant in this connection that the account here proposed clarifies many concrete features of first amendment adjudications, ${ }^{118}$ for example, the propriety of reasonable regulations of time, place, and procedure, ${ }^{119}$ the insistence that majority dislike of protected expression has no constitutional weight, ${ }^{120}$ the basis of the clear and present danger test, ${ }^{121}$ and the refusal

${ }^{115}$ See A. MeIkLEjohn, supra note 112. Meiklejohn has attempted to defend his view by interpreting the political quite broadly. Meiklejohn, The First Amendment Is An Absolute, 1961 Sup. CT. REv. 245, 255-57, 262-63. For a similar view without any such attempt, see Bork, Neutral Principles and Some First Amendment Problems, 47 IND. L.J. 1, 20-35 (1971). Such a view derives its moral plausibility and appeal from an ambiguity in the notion of being self-governing. It associates free expression with the general notion of personal autonomy and then conflates this notion with the idea of voting rights. Once the ambiguity is revealed, the view loses its appeal.

116 See Chafee, Book Review, 62 Harv. L. Rev. 891, 896-98 (1949).

117 There has, of course, been a significant line of cases which has enlarged the concept of state action, but the state action requirement remains intact. See, e.g., Lloyd Corp. v. Tanner, 407 U.S. 551 (1972) (no entitlement to exercise first amendment rights in a privately owned and operated shopping center merely because the public is generally invited to do business there); $c f$. Moose Lodge 107 v. Irvis, 407 U.S. 163 (1972) (regulation by a state liquor board not sufficient to make practices of a private club state action).

${ }^{118}$ As an explication, this account seems to have more explanatory power than other comparable general theories of the first amendment. Unlike Meiklejohn's theory, it accounts for the fact that free expression is not limited to politics. See A. Meiklejorn, supra note 112; see note 115 supra \& accompanying text. It also accounts for the clear and present danger test, unlike the work of Thomas Emerson. See T. EMERson, supra note 111; T. Emerson, Toward a General Theory of the First Amendment (1966).

${ }^{119}$ See, e.g., Cox v. Louisiana, 379 U.S. 536, 554-55 (1965); Poulos v. New Hampshire, 345 U.S. 395, 405 (1953); Kovacs v. Cooper, 336 U.S. 77 (1949); Saia v. New York, 334 U.S. 558 (1948); Cox v. New Hampshire, 312 U.S. 569, $574-76$ (1941).

${ }^{120}$ See, e.g., A Book Named "John Cleland's Memoirs of a Woman of Pleasure" v. Attorney General, 383 U.S. 413, 427 (1966) (Douglas, J., concurring); Kingsley International Pictures Corp. v. Regents, 360 U.S. 684, 688-89 (1959); Roth v. United States, 354 U.S. 476, 484 (1957); Terminiello v. Chicago, 337 U.S. 1, 3-5 (1949).

121 See, e.g., Brandenburg v. Ohio, 395 U.S. 444 (1969); Dennis v. United States, 341 U.S. 494 (1951). 
to limit the first amendment to the political. ${ }^{\mathbf{1 2 2}}$ It is equally clear that this account provides a framework from which the case law may be critically assessed both as regards proper extensions of first amendment rights, such as rights of access to the media, ${ }^{123}$ and the criticism of anomalies in existing case law which depart from its deepest moral strains.

\section{The Constitutionality of Obscenity Law}

It should now be possible to apply the foregoing explication of the obscene and the moral analysis of the first amendment to the issue raised in Miller $v$. California ${ }^{124}$ and Paris Adult Theatre I v. Slaton ${ }^{125}$ - the constitutionally permissible concept of the obscene.

Miller reaffirmed the holding of Roth $v$. United States ${ }^{126}$ that obscene expression is not protected by the first amendment. In addition, the Court, speaking through the Chief Justice, formulated a constitutional test for obscenity. The test is threefold:

(a) whether "the average person, applying contemporary community standards" would find that the work, taken as a whole, appeals to the prurient interest . . . ; (b) whether the work depicts or describes, in a patently offensive way, sexual conduct specifically defined by the applicable state law; and (c) whether the work, taken as a whole, lacks serious literary, artistic, political, or scientific value. ${ }^{127}$

This test imposes on states that wish to ban obscenity an obligation to formulate specific standards. Moreover, Miller limits the obscene to "representations or descriptions of ultimate sexual acts, normal or perverted, actual or simulated" or "of masturbation, excretory functions and lewd exhibition of the genitals." ${ }^{28}$

${ }^{122}$ See, e.g., Roth v. United States, 354 U.S. 476, 484 (1957) (all ideas with the slightest redeeming social value have first amendment protection); Joseph Burstyn, Inc. v. Wilson, 343 U.S. 495 (1952).

${ }^{123}$ This right has not yet been examined from the point of view afforded by contractarian moral theory. For a discussion of the right, see Barron, Access to the Press-A New First Amendment Right, 80 HaRv. L. Rev. 1641 (1967).

${ }^{124} 413$ U.S. 15 (1973).

125413 U.S. 49 (1973).

126354 U.S. 476 (1957).

127413 U.S. at 24 (quoting Roth, 354 U.S. at 489).

${ }^{128} \mathrm{Id}$. at 25 . The force of these requirements was made clear in Jenkins v. Georgia, 94 S. Ct. 2750 (1974), where the court overruled an obscenity conviction involving the movie Camal Knowledge on the ground that the depictions were not sexually explicit within the meaning of the applicable Miller tests. 
In effect, only hard-core scatology and pornography may be banned. ${ }^{129}$

On the other hand, the Miller test permits censorship wherever the allegedly obscene work is without "serious" value. ${ }^{130}$ Thus, a lighter burden is imposed on the prosecution than was imposed under the prior "utterly without redeeming social value" test. ${ }^{131}$ Moreover, reliance on local standards, ${ }^{132}$ within the bounds of the court's test, permits a variety of constitutionally permissible restrictions. Hence, a person's first amendment rights may be restricted in one jurisdiction without appeal to a national standard. ${ }^{133}$

The facts of Miller involved a conviction for mailing unsolicited sexually explicit material which is, of course, a problem of nonconsensual intrusion of offensive material. In Paris Adult Theatre I v. Slaton, ${ }^{134}$ however, a majority of the Court, again speaking through Chief Justice Burger, applied the Miller criteria for obscenity to an adult's fully informed and consensual access to obscene materials. The Court thus narrowly limited the holding of Stanley $v$. Georgia ${ }^{135}$ to its facts. There the Court invalidated a state statute prohibiting the possession and private use in one's home of obscene (pornographic) materials on the grounds of infringing the constitutional right of privacy. In Paris Adult Theatre, and other cases decided concurrently, the Court made clear that the constitutional right of privacy as regards the use of obscene materials applies only to one's home, not to any

129413 U.S. at 27-28. Thus, the Court accepts the view previously expressed by Justice Stewart. Ginzburg v. United States, 383 U.S. 463, 499 (1966) (Stewart, J., dissenting); Jacobellis v. Ohio, 373 U.S. 184, 197 (1964) (Stewart, J., concurring). Significantly, Justice Stewart dissents in Miller and Paris Adult Theatre, joining in the dissent of Justice Brennan. 413 U.S. at 73. The view that the constitutionally obscene should be limited to hard core materials had previously been urged by various commentators. E.g., Kalven, supra note 58 , at 13; Lockhart \& McClure, Censorship of Obscenity: The Developing Constitutional Standards, 45 MinN. L. Rev. 5, 58-68 (1960).

130413 U.S. at $24-25$.

131 A Book Named "John Cleland's Memoirs of a Woman of Pleasure" v. Massachusetts, 383 U.S. 413,419 (1966).

132413 U.S. at $30-34$. No suggestion is made that the value test would be applied relative to local community standards. Such a suggestion would be absurd. The literary and dramatic value, for example, of Shakespeare is not affected by the disvaluation of his work by some parochial community. In Hamling v. United States, 94 S. Ct. 2887 (1974), the Court made clear that the relevant community standards were not necessarily statewide.

${ }^{133}$ The Court thus rejected the previously urged view that standards to be applied were national, not local. E.g., Jacobellis v. Ohio, 378 U.S. 184, 192-93 (1964) (Brennan, J., opinion accompanying announcement of judgment of the Court).

134413 U.S. 49 (1973).

135394 U.S. 557 (1969). 
theatre, nor even to the transport of such materials in one's traveling bags for private use. ${ }^{136}$

Miller and Paris Adult Theatre, then, find obscenity, even for consenting adults, to be outside the protection of the first amendment, but the analysis of this Article suggests that the Court's decisions are wrong. An understanding of the moral function of the first amendment compels a conclusion contrary to the Court's; there should be a presumption that obscenity, like other forms of expression, falls within the protection of the first amendment.

To summarize, obscene communications, it has been proposed, implicate the improper abuse of basic bodily functions, the proper exercise of which is an object of basic self-esteem, and the improper abuse of which is an object of shame and disgust. A sufficient, though not a necessary, condition of the obscenity of a communication is that the act depicted be obscene.

On this view, the precise application of the notion of the obscene crucially depends on beliefs and attitudes involving precise and rigid definitions of the proper exercise of bodily functions. Thus, different cultures, with different beliefs and attitudes, may regard dissimilar acts or objects as obscene. Similarly, within a culture, individuals having discrepant beliefs and attitudes about proper bodily function may apply the label "obscene" to different phenomena. In the United States, for example, there are many people who, having certain attitudes toward proper sexual function, regard pornography as obscene because it reflects, for them, an improper exercise of sexual function. But others, not sharing those beliefs and attitudes, do not regard pornography as obscene, ${ }^{137}$ though they may think that other things, like depictions of coprophagy, are obscene.

An obscenity law, then, must be understood as a political expression of broader popular moral attitudes toward the putative proper use, and improper abuse, of the body. It is no accident that such laws have been used to forbid the transport of abortifacient and contraceptive information ${ }^{138}$ and dissemination of sex manuals ${ }^{139}$ and to prosecute advocacy of contraception and

136 United States v. Orito, 413 U.S. 139 (1973); United States v. 12 200-Ft. Reels of Film, 413 U.S. 123 (1973). See also United States v. Reidel, 402 U.S. 351 (1971).

${ }^{137}$ See notes 67-70 supra \& accompanying text. For a discussion of the studies relating to divergent American responses to pornography, see supra note 85, at 195-215.

${ }^{138}$ See note 31 supra; 18 U.S.C. $\$ 1461$ (1964), as amended, 18 U.S.C. $\S 1461$ (1970) (mail); 18 U.S.C. \$ 1462(c), as amended, 18 U.S.C. \$ 1462(c) (1970) (interstate commerce).

${ }^{139}$ See, e.g., United States v. Chesman, 19 F. 497 (E.D. Mo. 1881). But cf. Walker v. Popenoe, 149 F. 2d 511 (D.C. Cir. 1945); United States v. One Obscene Book Entitled 
population control. ${ }^{140}$ The moral attitudes behind such laws, directed against a supposed "abuse" of the body, were founded on a compound of religious, psychological, and medical beliefs basic to which was a deep fear of masturbation. ${ }^{141}$ Masturbation, it was believed, led directly to physical debility and even death, ${ }^{142}$ as well as crime and civil disorder. ${ }^{143}$

In judicial interpretation of the notion of the obscene, courts implicitly decide on and enforce popular attitudes about bodily function. Whatever may be the constitutional legitimacy of regulating obscene acts, it is impossible to see how regulating obscene communications can avoid raising the deepest first amendment problems. Because judicial application of obscenity laws necessarily enforces a particular attitude, albeit presumably majoritarian, about the contents of communication, it seems to be obnoxious in principle to the central moral purpose of the first amendment-to secure the greatest equal liberty of communication compatible with a like liberty for all. State prohibitions or regulations of communication are permissible, on this analysis, only to advance the system of greatest equal liberty. It is striking to compare this analysis with that adopted by the Court in Roth and reaffirmed in Miller and Paris Adult Theatre.

\section{A. The Historical Status of Obscenity in American Law}

The classical approach to interpretation of the first amendment is taken in two analytical steps. First, one asks whether the federal or state prohibition or regulation applies to a communication of the sort protected by the "freedom of speech, or of the press," guaranteed by the first amendment. Thus, displaying a red flag has been held to be a form of protected "speech," "144 but

"Married Love", 48 F.2d 821 (S.D.N.Y. 1931); United States v. Dennett, 39 F.2d 564 (2d Cir. 1930).

${ }^{140}$ See, e.g., United States v. Bennett, 24 F. Cas. 1093, No. 14,571 (C.C.S.D.N.Y. 1879); Regina v. Bradlaugh, 2 Q.B.D. 569 (1877), rev'd on other grounds, 3 Q.B.D. 607 (1878). But of Consumers Union of the United States, Inc. v. Walker, 145 F.2d 33 (D.C. Cir. 1944); United States v. One Book, Entitled "Contraception", 51 F.2d 525 (S.D.N.Y. 1931).

${ }_{141}$ See text accompanying notes 71-83 supra.

142 Comstock, for example, noted the case of a thirteen year old girl, in whose bureau he "found a quantity of the most debasing and foul-worded matter. The last heard from this child she was in a dying condition, the result of habits induced by this foul reading." A. Comstock, Traps for the Young 139 (R. Bremner ed. 1967).

${ }^{143}$ Comstock cited a number of instances where, in his view, access to obscene material led to robbery, burglary, and murder. A. Comstock, Frauds Exposed 437-39 (1880, reprinted 1969). See also A. Coмsтock, supra note 142, at 132-33, 169, 179.

144 Stromberg v. California, 283 U.S. 359 (1931). 
burning draft cards is not a protected type of communication. ${ }^{145}$ Assuming that protected speech is involved, one then asks whether the regulation or prohibition is justified by some clear or present danger that the state has a right to prevent, ${ }^{146}$ or by some countervailing state interest which overbalances the interest in free speech. ${ }^{147}$ The Supreme Court's consideration of the application of free speech standards to the publication of obscene materials ${ }^{148}$ has notably focused on the first step in the classic analytic approach, whether the obscene is protected speech at all. ${ }^{149}$

The initial and fundamental decision considering the first amendment issue involved in the control of allegedly obscene materials was the consolidated case of Roth $v$. United States and Albert $v$. California. ${ }^{150}$ Defining the obscene as "material which deals with sex in a manner appealing to the prurient interest,"151 the court upheld the constitutionality of both the federal and Cal-

145 United States v. O'Brien, 391 U.S. 367 (1968).

${ }^{146}$ Schenck v. United States, 249 U.S. 47, 52 (1919). The latest restatement of this proposition applies to advocacy that is both directed to and likely to incite or produce "imminent lawless action." Brandenburg v. Ohio, 395 U.S. 444, 447 (1969) (per curiam). Cf. Yates v. United States, 354 U.S. 298 (1957); Dennis v. United States, 341 U.S. 494 (195 1); Whitney v. California, 274 U.S. 357, 374 (1927) (Holmes \& Brandeis, JJ., concurring); Gitlow v. New York, 268 U.S. 652, 673 (1925) (Holmes \& Brandeis, JJ., dissenting); Abrams v. United States, 250 U.S. 616, 624 (1919) (Holmes \& Brandeis, JJ., dissenting). See also M. Shapiro, Freedom of SPEEch (1966).

147 Konigsberg v. State Bar, 366 U.S. 36 (1961); American Communications Association v. Douds, 339 U.S. 382 (1950). But cf. United States v. Robel, 389 U.S. 258 (1967).

148 The constitutionality of obscenity law has been assessed under other constitutional provisions besides the free speech clause of the first amendment. Thus, a Michigan general obscenity statute was struck down under the due process clause of the fourteenth amendment because it prohibited the reading of books suitable for adults on the ground that the books were not suitable for minors, Butler v. Michigan, 352 U.S. 380 (1957), and at least three Supreme Court justices now believe that much obscenity legislation should be invalidated on due process grounds. Paris Adult Theatre I v. Slaton, 413 U.S. 49, 73 (1973) (Brennan, J., dissenting with Stewart \& Marshall, JJ., concurring in the dissent). Applications of obscenity statutes have also been invalidated, at least in part, on grounds of a constitutional right of privacy, Stanley v. Georgia, 394 U.S. 557 (1969), and serious constitutional argument has been advanced that the establishment of religion clause of the first amendment is violated by obscenity statutes. Henkin, Morals and the Constitution: The Sin of Obscenity, 63 Colum. L. REv. 391 (1963). Nevertheless, the constitutional issues surrounding obscenity inevitably gravitate toward the free speech clause of the first amendment.

${ }^{149}$ It is significant, in this connection, that in the few cases, all prior to Roth, focusing on the second step, whether there is a clear and present danger of an evil that the state may prevent or some countervailing interest, courts have failed to find sufficient grounds to justify such prohibitions. See Roth v. United States, 237 F.2d 796, 801 (2d Cir. 1956) (Frank, J., concurring), aff'd 354 U.S. 476 (1957); Commonwealth v. Gordon, 66 Pa. D. \& C. 101 (1949) (Bok, J.), aff'd sub nom. Commonwealth v. Feigenbaum, 166 Pa. Super. 120, 70 A.2d 389 (1950).

150354 U.S. 476 (1957).

${ }^{151}$ Id. at 487. 
ifornia laws. The court, speaking through Justice Brennan, acknowledged that "[a]ll ideas having even the slightest redeeming social importance-unorthodox ideas, controversial ideas, even ideas hateful to the prevailing climate of opinion ..." are protected speech, ${ }^{152}$ but, on the basis of the "history of the First Amendment," it found that obscenity was not at all protected speech $^{153}$ within the meaning of the first amendment. It is difficult to fathom how the Court supposed that the development of obscenity law in the United States, which postdates the adoption of the Bill of Rights, clarifies the purposes of the first amendment. ${ }^{154}$ Colonial legislatures in America appear to have been either unprovoked by ${ }^{155}$ or indifferent to ${ }^{156}$ obscenity. Justice Brennan cited only one example of preconstitutional obscenity law: an early Massachusetts law forbidding obscene or profane mockery of religious services. ${ }^{157}$ This law, however, is more properly viewed as a religious establishment law than as a law against obscene literature or art in general, ${ }^{158}$ which is striking when contrasted with the Puritan propensity to supervise private conduct through the criminal law. ${ }^{159}$ In any event, there appear to have been no prosecutions under this law ${ }^{160}$ and when Massachusetts set out to suppress the Memoirs of a Woman of Pleasure in 1821, it relied on the common law misdemeanor of obscene libel. ${ }^{161}$ There appear to have been no prior prosecutions under the common law in Massachusetts either; ${ }^{162}$ the earliest American prosecution for common law obscene libel was in 1815 in Pennsylvania. ${ }^{163}$

${ }^{152}$ Id. at 484.

${ }^{153} \mathrm{Id}$.

${ }^{154}$ Cf. Rogge, "The High Court of Obscenity" I, 41 U. Col. L. REv. 1, 2-3 (1969). For useful general accounts of early American developments, see Alschuler, Origins of the Law of Obscenity, in United States Comm'n on Obscenity and Pornography, 2 TechinCAL REPORT 65, 73-79 (GPO ed. 1971); Alpert, Judicial Censorship of Obscene Literature, 52 HARv. L. REv. 40, 53-56 (1938); Lockhart \& McClure, Literature, the Law of Obscenity, and the Constitution, 38 Minn. L. REv. 295, 324-29 (1954).

${ }^{155}$ See Alschuler, supra note 154 , at 75.

${ }^{156}$ See United States v. Roth, 237 F.2d 796, 801, 806-09 (1956) (Frank, J., concurring).

${ }^{157}$ Act of March 19, 1712, ch. 6, $\S 19,1$ Acts and Resolves of the Province of Mass. Bay 682 (E. Ames \& A. Goodell compl. 1869); Act of May 13, 1711, Records of the States of the United States of America, Mass. B. 2, Reel I 1661-1742, Unit 7 (W.S. Jenkins ed. 1949) (microfilm).

${ }^{158}$ But see Alschuler, supra note 154, at 74-75 (broader scope inferred from preamble).

${ }^{159}$ See Nelson, Emerging Notions of Modern Criminal Law in the Revolutionary Era, 42

N.Y.U.L. REV. 450, 450-58 (1967).

${ }^{160}$ See Alschuler, supra note 154 , at 75.

${ }^{161}$ Commonwealth v. Holmes, 17 Mass. 336, 338 (1821).

162 See Alpert, supra note 154, at 53.

${ }^{163}$ Commonwealth v. Sharpless, 2 S. \& R. 91 (Pa. 1815); $c f$. Knowles v. State, 3 Day 103 (Conn. 1808) (dictum in case involving display of a monster). 
State laws regulating and prohibiting obscenity were adopted only after the passage of the first amendment, as part of the nineteenth century Anglo-American concern over pornography. ${ }^{164}$ The earliest law was a Connecticut statute of $1821 .{ }^{165}$ The first federal legislation was a customs statute passed in 1842.166 Even with these laws, prosecutions were relatively few until after the Civil War ${ }^{167}$ when the Committee for the Suppression of Vice, led by Anthony Comstock, took up the cudgels for purity in earnest. ${ }^{168}$ In short, the evidence for obscenity law contemporaneous with the passage of the first amendment is tenuous at best. Indeed, in the court of appeals Judge Frank argued that the framers of the Constitution were rather tolerant of literature that later generations regarded as obscene. ${ }^{169}$

In any event, the existence at the time of the adoption of the first amendment of laws, such as that against seditious libel, has never been supposed to conclude the question of the constitutionality of such laws. ${ }^{170}$ The basis for the decision in Roth lies not in history but in policy.

\section{B. The Propositional Nature of Obscenity}

The policy behind the Roth decision was that "the lewd and obscene ... are no essential part of any exposition of ideas, and are of such slight social value as a step to truth that any benefit that may be derived from them is clearly outweighed by the social interest in order and morality ...."171 In effect, obscene speech was relegated by the Court to a class of clearly communicative employments of speech which the Court has held not to be "free speech" within the meaning

${ }^{164} \mathrm{Cf}$. text accompanying notes 47-51 supra.

165 Act of May, 1821, ch. 22, $\$ 69,[1821]$ Conn. Stat. Laws 165. Cf. Act of Nov. 15, 1821 , ch. 12, § 23, [1824] Laws of Vt. 271. An earlier statute, Act of Mar. 16, 1798, § 12, [1800] N.J. Laws 331 , cited in Roth, 354 U.S. at 483 n.13, was directed against all shows and exhibitions for profit, not against obscenity in particular.

${ }^{166}$ Act of Aug. 30, 1842, ch. 270, § 28, 5 Stat. 566.

${ }^{167}$ See Lockhart \& McClure, supra note 154, at 324.

168 For an account of the social history associated with this development, see P. BOYER, Purity in Print: The Vice-Society Movement and Book Gensorship in America (1968). 169237 F.2d at 806-09.

${ }^{170}$ For a discussion of the crime of seditious libel at American common law, see $L$. LEVY, LegaCY of Suppression (1960). For the view that seditious libel was abolished by the first amendment, see Beauharnais v. Illinois, 343 U.S. 250, 272 (1952) (Black, J., dissenting); Abrams v. United States, 250 U.S. 616, 630-31 (1919) (Holmes, J., dissenting). See also Bridges v. California, 314 U.S. 252, 264-65 (1941); Grosjean v. American Press Co., 297 U.S. 233, 248-49 (1936) (first amendment prohibits taxes that restrict newspaper circulation, although such taxes were employed in England and America at the time of the adoption of the first amendment).

171354 U.S. at 485 (quoting with approval Chaplinsky v. New Hampshire, 315 U.S. 568, $571-72$ (1942) (emphasis added by the Court)). 
of the first amendment. Other members of that class are "fighting words", like the epithets "damned racketeer" and "damned fascist;"172 libels; ${ }^{173}$ and commercial uses of speech. ${ }^{174}$

It is quite clear that the Roth Court's observation applies most strongly to the use of verbal obscenities as epithets. ${ }^{175}$ Obscene epithets are obviously nonpropositional; they are conventionalized ways of expressing attitudes of disgust or contempt, which depend for their effect on the impropriety of their use. ${ }^{176}$ The Court could not have meant, however, that such expressions are not speech, within the meaning of the first amendment, merely because they are nonpropositional. It is quite clear that many forms of supposedly obscene materials, which Roth would put wholly outside the protection of the first amendment, are propositional; much hard core pornography, for example, rather precisely describes certain acts in propositional terms. Conversely, nonpropositional expressions are not per se excluded from the protection of the first amendment; even obscene epithets have been protected. ${ }^{177}$ It is also clear that forms of art not expressible in words alone or in words at all, such as motion pictures, are within the protection of the first amendment. ${ }^{178}$ Indeed, in Miller, the Court conceded first amendment protection to any work, even one with prurient appeal, that taken as a whole has "serious literary, artistic, political, or scientific value."179 This concession suggests that the prohibition of dodecaphonic music or modern dance, although such art forms do not express formal propositions, would be unconstitutional. The first amendment, thus, protects all communications, not just those in propositional form.

172 Chaplinsky v. New Hampshire, 315 U.S. 568 (1942). But $c f$. Cohen v. California, 403 U.S. 15 (1971) ("fighting words" statute invalidated for overbreadth as applied to a conviction for wearing a jacket carrying the statement "Fuck the Draft").

${ }^{173}$ See Gertz v. Robert Welch, Inc., 94 S. Ct. 2997, 3006-07 (1974); Beauharnais v. Illinois, 343 U.S. 250, 266 (1952). See also Rosenbloom v. Metromedia, Inc., 403 U.S. 29 (1971); New York Times Co. v. Sullivan, 376 U.S. 254 (1964).

${ }_{174}$ See Pittsburgh Press Co. v. Pittsburgh Comm'n on Human Relations, 413 U.S. 376 (1973); Breard v. Alexandria, 341 U.S. 622 (1951); Valentine v. Chrestensen, 316 U.S. 52 (1942). But see Redish, The First Amendment in the Marketplace: Commercial Speech and the Values of Free Expression, 39 Geo. WASH. L. REv. 429 (1971).

175 In the quoted portion of Chaplinsky, text accompanying note 171 supra, the Court found support in Z. Chafee, Free SPEech IN THE UNITED STAtes 150 (1941). 315 U.S. at 572 n.5. By way of example, Chafee stated: "The man who swears in a street car is as much of a nuisance as the man who smokes there. Insults are punished like a threatening gesture, since they are liable to provoke a fight."

${ }^{176}$ See text accompanying notes 32-38 supra.

${ }^{177}$ Cohen v. California, 403 U.S. 15 (1971) ("Fuck the draft").

${ }^{178}$ Jenkins v. Georgia, 94 S. Ct. 2750 (1974); Joseph Burstyn, Inc. v. Wilson, 343 U.S. 495 (1952); see R. RANDALI, Censorship of the Movies 9-32 (1968).

179413 U.S. at 24. 
What, then, can the Supreme Court mean by saying in Roth and reaffirming in Miller and Paris Adult Theatre that the obscene does not express ideas and is not essential to their expression? The claim seems at bottom to be that obscene expression is essentially a form of saying something which can be equally well said without using that form. The obscene is like an unpleasant personal mannerism, for instance, a belligerent tone, that bears no real relation to the speaker's communicative intention. The idea is that the content of an obscene expression may be equally well expressed without being obscene: a pornographic depiction could be expressed in colorless medical language that does not appeal to prurient interest; or a novel dealing with the cruelties of sexuality without emotion may equally well express its point without certain vivid pornographic depictions. ${ }^{180}$

But this view, once baldly stated, is clearly premissed on a false philosophy of language as well as a false moral theory of the first amendment. The meaning or communicative intention ${ }^{181}$ of an obscene expression is inextricably intertwined with its obscene content. To remove the obscenity from an expression is precisely to remove an essential element of meaning. Verbal obscenities, for example, carry a very special meaning which cannot be captured in any other way. Consider reading the "Watergate tapes" transcripts with the expletives restored. At one point Nixon advised Haldeman and Ehrlichman to "use the most vicious libel lawyer there is. I'd sue every (expletive deleted) (unintelligible)." ${ }^{182}$ It would surely impart a very different sense and reflect very differently on the mind of the former President if he had said "I'd sue every unsavoury scoundrel who criticized the Administration" than if he had used obscene epithets in place of "unsavoury scoundrel." 183 Or consider Lenny Bruce's monologues with the obscenities removed; the comic and satiric meaning would not merely be modified, it would be completely transformed. ${ }^{184}$ Similarly, the use of the obscene in literature-the depictions of excretion and the like in Pope ${ }^{185}$ and Swift ${ }^{186}$ come

${ }^{180}$ This notion seems to be the basis for the test of overall or predominant effect: whether the objectionably obscene passage is part of an overall nonobscene effect. 413 U.S. at 24.

181 For a systematic development of this notion of meaning, see S. Schiffer, MEanING (1972); Grice, Meaning, 66 Philos. Rev. 377 (1957).

182 The White House Transcripts 737 (G. Gold ed. 1974).

${ }^{183} \mathrm{Cf}$. Haiman, Speech v. Privacy: Is There A Right Not To Be Spoken To?, 67 Nw. U.L.

REv. 153, 188-92 (1972).

${ }^{184}$ For the prosecutor's view of Bruce, see R. KuH, supra note 57, at 175-211.

${ }^{185}$ See notes 27 \& 36 supra.

${ }^{186}$ See note 35 supra. 
to mind-gives precise expression to the satirical disgust which is part of the complex communicative intentions of these works. To eliminate the obscene from such works, as in Bowdler's expurgations of Shakespeare, ${ }^{187}$ impoverishes and distorts their meanings.

Hence, a prohibition of the obscene is a prohibition on a certain kind of meaning. It is fundamentally unreasonable to say, as the Supreme Court did in Roth and reaffirmed in Miller and Paris Adult Theatre, that this is not an essential form of speech within the meaning of the first amendment. It is precisely that; by outlawing it, the Court makes criminal a certain content of communication.

If the Court does recognize the expressive function of the obscene, it must then be saying that this type of content in communication is without constitutional value. This view appears to be confirmed by either the test of obscenity employed in the Roth line of cases or that propounded in Miller. In Roth, Justice Brennan described obscenity as "utterly without redeeming social importance," 188 and in $A$ Book Named "John Cleland's Memoirs of a Woman of Pleasure" $v$. Massachusetts, ${ }^{189}$ he specified that one part of the test for obscenity was whether or not the material was "utterly without redeeming social value." ${ }^{190}$ Under this test, even material with a dominant appeal to a prurient interest in sex, and patently offensive to contemporary community standards, might not be illegally obscene, if it had any redeeming value. In Miller, however, Chief Justice Burger explicitly disavowed the "utterly without redeeming social value" test, permitting a finding of obscenity if the work "lacks serious literary, artistic, political, or scientific value."191

But by what criteria is value judged? It should be clear by now that there is no evidence, of a generally acceptable empirical kind, that hard core pornography is without value. ${ }^{192}$ On the contrary, various dispassionate empirical studies show that the use of hard-core pornographic materials has a significant and

187 W. Shakespeare, The Family Shakespeare (Ist ed. T. Bowdler ed. 1807).

188354 U.S. at 484.

189383 U.S. 413 (1966).

190383 U.S. at 418.

191413 U.S. at $24-25$.

192 See, e.g., G. GoRER, supra note 19, at 217-31; REPORT, supra note 85, at 41, 15463, 266-70; Money \& Athanasiou, Pornography: Review and Bibliographic Annotations, 115 Aм. J. OвsTeт. \& Gyn. 130, 143-46 (1973); $c f$. Murphy, The Value of Pornography, 10 Wayne L. Rev. 655 (1964). See also Gerber, A Suggested Solution to the Riddle of Obscenity;, 112 U. PA. L. Rev. 834, 850 (1964). 
valued function in the life of many Americans. ${ }^{193}$ In saying that the obscene is not constitutionally protected at all, and in identifying the obscene with the pornographic, ${ }^{194}$ the Court at bottom takes its standards of value from majority moral attitudes. In so doing, the Court violates the central moral value of the first amendment, that majority attitudes per se are not a constitutionally valid basis for regulating or prohibiting expressive communications.

In an important sense, therefore, the Court's obscenity decisions are profoundly political ${ }^{195}$ and violate the ideal of neutral principles of constitutional adjudication. ${ }^{196}$ There is today in America substantial and growing disagreement regarding many questions of sexual and personal morality, ${ }^{197}$ a few of which have already surfaced dramatically in major constitutional adjudications. ${ }^{198}$ Part of this disagreement is over notions of proper sexual function, with serious arguments being proposed for major constitutional attacks on various statutes regulating sexual function. ${ }^{199}$ The revaluation of the obscene is one aspect of this de-

${ }^{193}$ See note 192 supra; M. Goldstein \& H. Kant, Pornography and Sexual Deviance 147-53 (1973); N. Polsky, Hustlers, Beats, and Others 186-202 (1967); RePORT, supra note 85, at 128-34. The typical pornography users in America appear to be white, middle aged, married males who had comparatively less sexual experience in adolescence than the norm. REPORT, supra note 85 , at 128-34.

${ }^{194}$ See note 58 supra \& text accompanying notes 127-29 supra.

195 Thus, attempts to exclude the obscene from the protection of the first amendment on the ground that the obscene is in no sense political fail even on their own premises. For such an attempt, see Anastaplo, Obscenity and Common Sense: Toward a Definition of "Community" and "Individuality", 16 ST. Louis U.L.J. 527, 551-52 (1972).

${ }^{196}$ See Wechsler, Toward Neutral Principles of Constitutional Law, 73 Harv. L. REv. 1 (1959). For the debate engendered by this article, see A. Bickel, The LeAST DANGerous Branch 49-65 (1962); Black, The Lawfulness of the Segregation Decisions, 69 YALE L. J. 421 (1960); Henkin, Some Reflections on Current Constitutional Controversy, 109 U. PA. L. REv. 637, 652-55 (1961); Miller \& Howell, The Myth of Neutrality in Constitutional Adjudication, 27 U. ChI. L. Rev. 661 (1960); Pollak, Racial Discrimination and Judicial Integrity: $A$ Reply to Professor Wechsler, 108 U. PA. L. REv. 1 (1959); Wright, Professor Bickel, the Scholarly Tradition, and the Supreme Court, 84 HaRv. L. REv. 769 (1971).

197 See, e.g., R. Bell, Premarital Sex in a Changing Society (1966); Beyond Monogamy (J. Smith \& L. Smith eds. 1974); Dep'tal Comm. on Homosexual Offenses \& Prostitution, Report of the Committee on Homosexual Offenses and Prostitution Report CMnd. No. 247 (1957) (Wolfenden Report); D. KLAich, Woman Plus Woman (1974). Among the numerous books on the general topic ofchanging sexual morals are L. Lipton, The Erotic Revolution (1965); W. Reich, The Sexual. Revolution (4th ed. rev. 1969).

${ }^{198}$ See, e.g., Roe v. Wade, 410 U.S. 113 (1973) (abortion); Griswold v. Connecticut, 381 U.S. 479 (1965) (contraception).

${ }^{199}$ See, e.g., W. Barnett, Sexual Freedom and the Constirution (1973); Special Student Contribution, Homosexuality and the Law-An Overview, 17 N.Y.L.F. 273, 295-99 (1971); Comment, Private Consensual Adult Behavior: The Requirement of Harm to Others in the Enforcement of Morality, 14 U.C.L.A.L. REv. 581, 599-603 (1967). 
bate. ${ }^{200}$ In this context, pornography can be seen as the unique medium of a vision of sexuality, a "pornotopia"201 - a view of sensual delight in the erotic celebration of the body, a concept of easy freedom without consequences, a fantasy of timelessly repetitive indulgence. In opposition to the Victorian view that narrowly defines proper sexual function in a rigid way that is analogous to ideas of excremental regularity and moderation, ${ }^{202}$ pornography builds a model of plastic variety and joyful excess in sexuality. In opposition to the sorrowing Catholic dismissal of sexuality as an unfortunate and spiritually superficial concomitant of propagation, ${ }^{203}$ pornography affords the alternative idea of the independent status of sexuality as a profound and shattering ecstasy. ${ }^{204}$

Within the perspective of the evolving national debate over sexual morality and the Supreme Court's repeated support of an "uninhibited marketplace of ideas," ${ }^{205}$ it is difficult to see why the pornographic vision should not have a place in the marketplace of ideas beside other visions that celebrate the life of the mind, the sanctity of ascetic piety, or the usefulness of prudent self-discipline. ${ }^{206}$ In excluding the pornographic vision from the marketplace, the Court fundamentally fails to make a "morally neutral judgment . . . of obscene material . . .,"207 for in applying

${ }^{200}$ See H. Ellis, The Revaluation of Obscenity, in More Essays of Love and Virtue 103-42 (1931); M. ERnst \& W. Seagle, To the Pure . . . 250-62 (1928); Goodman, supra note 69; $c f$. D. Loth, The ERotic in Literature 187-89 (1961).

201 I take the word from S. MARCus, supra note 49, at 216, 268-74. See also P. Michelson, The Aesthetics of Pornography 1-13, 233-41 (1971).

${ }^{202}$ See notes 74-85 supra \& accompanying text.

${ }^{203}$ See notes 71-74 supra \& accompanying text.

${ }^{204}$ Pornography is also seen as the unique medium for giving expression to the transcendence of the personality by sexual transgression. S. Sontag, STYLES of RadiCAL Will 35-73 (1969); $f f$. S. DeBeauvorr, Must We BuRn SAde? (A. Michelson transl. 1953)

${ }^{205}$ Red Lion Broadcasting Co. v. FCC, 395 U.S. 367, 390 (1969); New York Times Co. v. Sullivan, 376 U.S. 254, 270 (1964); Associated Press v. United States, 326 U.S. 1, 20 (1945). The marketplace concept is attributable to Justice Holmes. Abrams v. United States, 250 U.S. 616, 630 (1919) (Holmes, J., dissenting).

${ }^{206}$ One argument that could be made in this connection is that pornographic materials are unequal combatants on the battlefield of truth and, accordingly, must be forbidden; otherwise the opposing ideas would have no fair chance. Given the panoply of rituals and traditions which opposing ideas can and do appeal to, it is difficult to see how this argument could be taken seriously without putting restrictions on the appeal to rituals and traditions. Even assuming the argument deserves attention, its appeal rests on one of two unspoken, and morally unspeakable, assumptions: either the object of competition among conflicting ideas is not the victory of truth, at least if that truth is obscene, or any view that appeals to man's baser instincts is presumptively less valuable than its innate competitive advantage would indicate. It should be obvious that these arguments are simply more manifestations of non-neutral principles of adjudication.

207 Paris Adult Theatre I v. Slaton, 413 U.S. 49, 69 (1973). 
the concept of the obscene it affirms one moral and political view and denies another.

To argue from the social value of pornography is to meet the Court on its own terms and to dispute the outcome of its balancing test. One may equally reject the constitutional validity of the balancing approach itself; indeed, the contractarian moral theory of the first amendment requires us to do so. The moral basis of the first amendment is not merely a utilitarian calculus of the political usefulness of a debate on divergent points of view. Rather, the first amendment rests more fundamentally on the moral liberties of expression, conscience and thought; these liberties are fundamental conditions of the integrity and competence of a person in mastering his life and expressing this mastery to others. The freedom to determine the contents of one's communications is fundamental to this mastery. Without this freedom, one lacks a basic ingredient of self-determination.

There is no reason whatsoever to believe that the freedom to determine the sexual contents of one's communications or to be an audience to such communications is not as fundamental to this self-mastery as the freedom to decide upon any other communicative contents. On the contrary, one of the central aims of developing methods of sex therapy in our culture is to help couples in "learning to communicate . . . in an area that heretofore in our culture has been denied the dignity of freedom of communication." 208 That obscenity law has been a traditional instrument of this denial is explicit in the historic utility of obscenity laws for attacking sex education and instruction, ${ }^{209}$ as well as in the recent attempts to ban pornography per se. The consequence of these assaults is not only a denial of a reasonable understanding of the varieties of pleasurable sexual function, ${ }^{210}$ but also a crippling debasement of the human capacity to master one's sexual life in the light of independent judgment.

Viewed in this manner, it is clear that the obscene falls within the protection of the first amendment and should be accorded whatever protection is given other forms of speech. ${ }^{211}$ The rele-

${ }^{208}$ W. Masters \& V. Johnson, Human Sexual Inadequacy 204 (1970).

${ }^{209}$ See notes $31,138-40$, supra \& accompanying text.

210 Thus, some popular sex manuals recommend the use of pornography. E.g., THE Joy of SEx 208-09 (A. Comfort ed. 1972). Interestingly, the Commission on Obscenity and Pornography adopted its proposal for the liberalization of obscenity law in light of its recommendations of the need for better sex education. REPORT, supra note 85, at 47-48, 58, 265-79. For an identical view, see B. Russell, supra note 69 , at 93-117.

${ }^{211}$ For related arguments leading to similar conclusions, see M. ERNST \& W. SEAGLE, 
vant constitutional question, therefore, is whether restrictions on the obscene are coherent with the principle of the greatest equal liberty of communication compatible with a like liberty for all.

\section{Equal Liberty and the Protection of Moral Standards}

Initially, it is important to be clear how the constitutional principle of equal liberty, as formulated and derived in this Article, is to be understood. In deriving the principle, we observed that the value of free expression turned on the existence of developed capacities of rational choice. ${ }^{212}$ Thus, the principle is not intended to apply to persons presumably lacking rational capacities, such as children. In addition, the liberty of communication was so interpreted that the liberty of expression correlates with the liberty of others to choose to be or not to be an audience. It follows, therefore, that there should be no constitutional objection on free expression grounds to the reasonable regulation of the distribution of obscene materials to children. ${ }^{213}$ Similarly, the state could prohibit the distribution of photographic pornography involving minors as subjects, because the child subjects could not have made a rational choice and their exploitation is not to be encouraged by permitting their exploiters to obtain the fruits of what is justifiably regarded as a crime. ${ }^{214}$ Nor is there any objection to the reasonable regulation of the obtrusive distribution of the obscene, in order to protect the liberty of persons not to be an audience, if they so choose. ${ }^{215}$ But this argument is far different from the attempt, in Paris Adult Theatre, to justify the general prohibition of the obscene because of "the interest of the public in the quality of life and the total community environment, [and] the tone of commerce in the great city centers ...."216 Any interest of this kind hardly justifies a general prohibition of all

supra note 200, at 188-286; T. Schroeder, “Obscene" Literature and Constitutional LAw 74-128 (1911).

212 See text accompanying notes 94-98 supra.

${ }^{213}$ It may be, however, that there are good empirical reasons for believing that such laws are not justified as a matter of sound policy. See, e.g., Larsen \& Wolfgang, Statements, in REPORT, supra note 85, at 375-77.

214 The same rationale would apply to any obscene depiction obtained by the use of nonconsenting subjects.

${ }^{215}$ Cf. Schwartz, Morals Offenses and the Model Penal Code, 63 Colum. L. REv. 669, 681 (1963). Compare Breard v. Alexandria, 341 U.S. 622 (1951), with Martin v. Struthers, 319 U.S. 141 (1943). The qualification regarding reasonable avoidability rests on the moral idea that a person cannot be heard to complain when he has voluntarily and rationally undertaken to inflict a pain or offense on himself. See, D.A.J. Richards, supra note 15, at $177-79$; cf. Feinberg, supra note 60 , at 103-04.

216413 U.S. at 58. 
pornographic materials. At most, it would justify some form of regulatory zoning of the place of sale of such materials and some kind of restriction on their obtrusive sale. ${ }^{217}$

Having formulated the relevant moral and constitutional principle to permit some reasonable restrictions on complete individual freedom, we must recall that any qualification of liberty of expression can be justified only on the basis of facts ascertainable by generally acceptable empirical methods. ${ }^{218}$ One quite relevant set of facts would be empirical support for the view that publication and use of obscene materials are "social poisons,"219 leading directly to disease, death, crime, and social disorder-in short, the Victorian view. ${ }^{220}$ Were these beliefs true, or even supported by substantial evidence, it is obvious that the principle of equal liberty would justify restrictions on obscene materials. In such circumstances the circulation of obscene materials would, of necessity, undermine the constitutional order of equal liberties. Certain of these Victorian beliefs, such as that regarding the evils of masturbation, are regarded today as medically ludicrous. ${ }^{21}$ There remains an intuition, though, that pornography threatens the public safety. In Paris Adult Theatre Chief Justice Burger advances this sort of argument, citing a minority report of the Commission on Obscenity and Pornography ${ }^{222}$ that "indicates . . . at least an arguable correlation between obscene material and crime." 223 In a manner that can only be regarded as disingenuous, the Court flatly ignores the great body of empirical evidence that shows there to be no empirical basis for such a view. ${ }^{224}$ Without the requisite empirical foundation,

${ }^{217}$ For a proposed statute and a discussion thereof, see R. KUH, supra note 57 at 269-79.

${ }^{218}$ See text accompanying note 105 supra.

${ }^{219}$ The metaphor of poison was particularly favored by Anthony Comstock. See, A. Сомsтоск, supra note 143, at 388-89; A. Coмsтock, supra note 142, at 174, 175, 179, $182,206,242$.

${ }^{220}$ See notes 74-83 supra \& accompanying text.

221 See, e.g., A. Comfort, supra note 76, at 69-113. For statements of the normality and useful functions of masturbation, see Sexual Behavror and Personality CharacTERISTICs 239-76 (M. DeMartino ed. 1963). For statistical background, see P. GebHard, J. Gagnon, W. Pomeroy \& C. Christenson, Sex Offenders 486-514 (1965); A. Kinsey, W. Pomeroy \& C. Martin, Sexual Behavior in the Human Male, 497-516 (1948); A. Kinsey, W. Pomeroy, C. Martin \& P. Gebhard, Sexual Behavior in the Human FEMALE 132-90 (I 953).

${ }^{222}$ In fact, the main focus of the Hill-Link Minority Report is the argument from protecting moral standards discussed below. See Hill \& Link, Statements, in REPORT, supra note 85 , at $383,385-86$.

223413 U.S. at 58.

224 See, e.g., P. Gebhard, J. Gagnon, W. Pomeroy, \& C. Christenson, supra note 221 , at 403-09, 669-92; REPORT, supra note 85, at 215-43; cf. M. GoldDTEIN \& H. KANT, supra 
the supposed threat to the public safety provides no justification for restricting the circulation and use of obscene materials.

One set of facts for which there is evidence, however, seems to allow at least some prohibition of the obscene consistent with the equal liberty principle. These facts relate to those special circumstances where the use of verbal obscenities as direct personal insults is clearly likely to lead to physical violence, thus causing a breakdown of the relations of equal liberty. ${ }^{225}$ This quite specific set of facts, which justifies only a very narrow qualification to the constitutional protection of obscene speech, has, however, been supposed by the Supreme Court to render the obscene outside the protection of the first amendment altogether. ${ }^{226}$ This argument is certainly among the more unfortunate examples of bad judicial reasoning, for it commits the obvious fallacy of overgeneralization and quite blatantly misuses authority to justify an unsupportable result.

It would appear, then, that no general prohibition of obscene communications seems justifiable on the basis of the facts capable of empirical confirmation. One final kind of argument, however, has been supposed by the Court to justify such a general prohibition, the argument from preserving moral standards. Having laid out his arguments from the "tone of commerce" and from "public safety," Justice Burger next proposes the general argument that society can forbid all access to pornographic materials in order to protect moral standards. The majority opinion cites in extenso ${ }^{227}$ a statement of Professor Bickel to the effect that to allow people consensually to gather to view such materials, in a way not obtrusive on others,

is to affect the world about the rest of us, and to impinge

note 193, at 139-53. Indeed, Denmark's experience was that repeal of its obscenity statute, as applied to consenting adults, lowered the rate of sex crimes. See REPORT, supra note 85, at 230-32; Ben-Veniste, Pornography and Sex Crime: The Danish Experience, in UnITED States Comm'n on Obscenity \& Pornography, 7 Technical Report 245 (1971); Kutschinsky, Towards an Explanation of the Decrease in Registered Sex Crimes in Copenhagen, in id. 263. For a summary of earlier studies, see Cairns, Paul \& Wishner, Sex Censorship; The Assumptions of Anti-Obscenity Laws and the Empirical Evidence, 46 MinN. L. Rev. 1009 (1962).

${ }_{225}$ Compare Chaplinsky v. New Hampshire, 315 U.S. 568 (1942), with Cohen v. California, 403 U.S. 15 (1971).

${ }^{226}$ See notes 171, 172, \& 175 supra \& accompanying text. The Court's reliance in Roth on the quoted portion of Chaplinsky, 354 U.S. at 485, which in turn relies on Chafee's work, 315 U.S. at 572 n.5, is misplaced. Chafee viewed these facts as justifying application of the "clear and present danger" test, or some variation thereof, but not as putting the obscene outside the protection of the first amendment altogether. See Z. ChafeE, Government and Mass Communications 49-61 (1947).

227413 U.S. at 59. 
on other privacies [for] [e]ven supposing that each of us can, if he wishes, effectively avert the eye and stop the ear (which, in truth, we cannot), what is commonly read and seen and heard and done intrudes upon us all, want it or not. ${ }^{228}$

If the substance of this argument is that permitting any form of disapproved conduct between or among consenting adults violates the rights of privacy of those who disapprove of this conduct, it is surprising that it can be supposed by the Court to deserve any weight whatsoever. How, precisely, is my right of privacy violated by the consensual conduct of others? This argument amounts to nothing more than the claim that knowledge of the existence of certain disapproved conduct suffices without more to justify legal prohibition of that conduct. Further evidence or reasoning of any kind is unnecessary. As such, it is an extension of the traditional argument, urged by Stephen ${ }^{229}$ against $\mathrm{Mill}^{230}$ and, more recently, by Devlin ${ }^{231}$ against Hart. ${ }^{232}$ But the traditional argument at least assumed that the condemned conduct had a weakening effect on society. At bottom, this argument rests on the crude moral confusion between an obtrusive offense and the offense derived from the mere knowledge of something. It must be rejected not only because it is intellectually indefensible, but also because its conclusions are morally outrageous. It would dilute the moral force of liberty into the empty and vapid idea that people be allowed to do that to which no one has any serious objection. ${ }^{233}$ It would elevate every form of popular prejudice, bigotry, and intolerance, without more, into a moral basis for law. The Court has consistently and rightly rejected such arguments. ${ }^{234}$ Majority attitudes per se, unsupported by reasoning of any intelligible kind, do not rise to the dignity of moral reasoning which

${ }^{228}$ Bickel, 22 Pub. INTEREST 25-26 (1971). For a discussion of the damaging effects of pornography on the viewer or reader, see Steiner, Night Words: High Pornography and Human Privacy, in Perspectives on Pornography 96 (D. Hughes ed. 1970).

${ }^{229}$ See J. Stephen, Liberty, Equality, Fraternity 135-78, esp. 138-39 (R. White ed. 1967).

${ }^{230}$ J.S. MiLl, supra note 98, at 91-113, esp. 100-01. See also W. Von Humboldr, The Limits of State Action 55-70 (J. Burrow ed. 1969).

${ }^{231}$ P. Devlin, The Enforcement of Morals (1965).

232 H.L.A. HaRt, Law, Liberty, and Morality (1963).

${ }^{233}$ Cf. id. 46-47.

${ }^{234}$ See, e.g., Roe v. Wade, 410 U.S. 113 (1973) (abortion); Eisenstadt v. Baird, 405 U.S. 438 (1972) (contraception for unmarried persons); Loving v. Virginia, 388 U.S. 1 (1967) (miscegenation); Griswold v. Connecticut, 381 U.S. 479 (1965) (contraception); Brown v. Board of Educ., 347 U.S. 483 (1954) (segregated education). 
can justify deprivation of liberty. ${ }^{235}$ They are merely intractable prejudices which the state should circumscribe where it is necessary to protect the system of equal liberties, rather than elevate into law. ${ }^{236}$

If this argument is wrong as applied to acts, it is even more palpably so as applied to communications. The first amendment rests on the moral status and weight of freedom of expression. Notwithstanding the attitudes of the majority, free expression is granted to the most despised minorities who advance causes condemned by the majority. To appeal to the unfounded attitudes of the majority, as this argument seems to do, in order to restrict the free expression of the unpopular minority, is precisely to withhold the value of free expression where it is most urgently required.

There is another form of this argument, however, that is not similarly objectionable in moral and constitutional principle, which the Court most likely had in mind. ${ }^{237}$ According to this form of the argument, there are certain demonstrable moral virtues or character traits which citizens of a stable constitutional democracy must have. Because obscenity, as a necessary factual matter, undermines these virtues, it leads to the breakdown of the constitutional order of equal liberties. Therefore, it is justifiable to prohibit obscenity on grounds of the equal liberty principle. ${ }^{238}$

While this argument has the general form of an acceptable moral and constitutional argument for limiting free speech, it is fundamentally circular, and its empirical premises are not, in fact, supported by evidence. Its circularity derives from unexamined assumptions. For example, it identifies the virtues required for democratic citizenship with the virtues specified by a quite special,

${ }^{235}$ For an account of moral reasoning, see D.A.J. Richards, supra note 15, at 75-292.

${ }^{236}$ Cf. Barnett, Corruption of Morals, 2 LAw \& Soc. ORDER 189-243 (1971); Dworkin, Lord Devin and the Enforcement of Morals, 75 Y YLE L.J. 986 (1966).

${ }^{237}$ See 413 U.S. at 59-60, where the court refers to the maintenance of a "decent society."

${ }^{238}$ The best statement of this view is H. Clor, Obscenity and Public Morality (1969). See also Berns, Pornography vs. Democracy: The Case for Censorship, 22 Pub. InTEResr 3 (1971); Kristol, Pornography, Obscenity and the Case for Censorship, N.Y. Times, Mar. 28, 1971, § 6 (Magazine), at 24; Elliot, Against Pornography, Harper's MaG., Mar. 1965, at 51; van den Haag, in CENSORSHIP: For AND Against 143 (1971); van den Haag, Quia Ineptum, in "To DEPRAVE AND CoRRUPT", supra note 18, at 109. For a general statement of this approach to the analysis of first amendment adjudications, see W. BERNS, Freedom, VirTue and the First AMENDMeNt 228-257 (1965). For the great classical statements of the position today defended by these authors, see Plato, The Republic 321-59 (F. Cornford transl. 1945); J.-J. ROuSSEAU, LeTter TO M. D'Alembert ON THE THEATRE (A. Bloom transl. 1960). 
religiously informed sexual morality ${ }^{239}$ that regards pornography as repugnant to its narrow definition of proper sexual function. ${ }^{240}$ It also assumes that pornography disconnects sex and love in a damaging way. ${ }^{241}$ These assumptions will not bear critical examination, however. There is no reason whatsoever to identify the virtues of democratic citizenship-public spiritedness, civic responsibility, democratic tolerance, mutual respect-with the virtue of rigid abstinence from pornographic material. ${ }^{242}$ Indeed, there is no consensus in our culture that such abstinence is a virtue; ${ }^{243}$ even some religiously informed sexual moralities are now tolerant of obscene materials. ${ }^{244}$ Further, unless one begs the question and assumes that love is properly defined by one narrow view of its proper expression, there is little empirical reason to suppose that pornography disconnects sex and love in a damaging way. On the contrary, some suppose that pornography may be a healthy influence, expressing a frank understanding of the integrated relation of emotion and its bodily expressions. $^{245}$

Surely good citizenship is compatible with many sexual styles and moralities. Indeed, one might suppose that the virtues of democratic tolerance and mutual respect are fostered by practicing tolerance toward different sexual moralities and by insistence on maintaining constitutional liberties of free speech for all groups. ${ }^{246}$

In any event, sexual moralities and pornography cannot be treated as unified phenomena. Different behaviors and materials appeal to different tastes. Even if the Court should conclude that one class of materials, sadistic obscenity for example, does have a deleterious effect on some fundamental democratic virtue, such as mutual respect, that conclusion would have no bearing on

${ }^{239}$ On the notion of sexual morality, see Ruddick, On Sexual Morality, in Moral Problems 85 (J. Rachels ed. 1971).

${ }^{240}$ Namely, a certain kind of disciplined, child-rearing, marital heterosexuality. See, e.g., text accompanying notes 71-73 supra.

${ }^{241}$ See Kristol, supra note 238 , at $24,112$.

${ }^{242}$ For a similar distinction, see R. MCKeon, R. Merton \& W. Gellhorn, The FreedOM TO READ 23-24 (1957).

${ }^{243}$ See note 69 supra.

${ }^{244}$ See, e.g., A Book Named "John Cleland's Memoirs of a Woman of Pleasure" v. Massachusetts, 383 U.S. 413, 433 (app. to opinion of Douglas, J., concurring; an address by a clergyman urging that Fanny Hill is a moral piece of literature); $f f$. Jones, Statement, in REPORT, supra note 85 , at 374.

245 See note 210 supra.

${ }^{246}$ See generally J. RAwLs, supra note 86, at 453-62; D.A.J. RICHARDS, supra note 15, at $242-78$. 
other types of obscene materials, such as depictions of cunnilingus, that have no ramifications for democratic virtues. Furthermore, although it is plausible that sadistic materials imply a lack of mutual respect in sexual relations, in order to justify the suppression of even sadistic materials the Court would have an obligation to find that attitudes in sexual fantasy cause destructive civic attitudes and behavior. According to the "outlet" theory of aggressive fantasy, however, quite the contrary would be true. ${ }^{247}$

In fact, there is no evidence of any generally accepted empirical kind that access to pornography in general has an adverse effect on character traits. ${ }^{248}$ People's capacity for responsible behavior and moral sensitivity does not seem to be affected by access to pornography. Nor is there any evidence that access to pornography causes social or cultural breakdown. ${ }^{249}$ Without evidence on these matters, the argument from preserving civic virtues is untenable. The presumption must be in favor of unrestricted freedom of expression; restrictions must be justified by appeal to convincing empirical evidence.

In depending on the argument from preserving moral standards to support its decision, then, the majority of the Court must be erecting some special notion of sexual morality into constitutional law. But on what constitutional basis does it do so? There are, no doubt, certain sexual moralities, based on special religious perceptions, ${ }^{250}$ which sharply condemn access to pornography. Special a priori religious perceptions of this kind, however, are not constitutionally admissible in interpreting the application of the equal liberty principle. ${ }^{251}$ Accordingly, such perceptions cannot be the basis of a constitutional justification of limitations on

${ }^{247}$ For example, de Sade himself, when released from the torments of his prison life, refused to use legal power to seek vengeance on his tormentors and was notable in his time for advocating abolition of the death penalty. G. Gorer, supra note 19, at 210.

${ }^{248}$ See REPORT, supra note 85, at 202.

249 The argument that it does lead to social breakdown, as suggested in J. STEPHEN, supra note 229 , and P. DevLIN, supra note 231 , rests on the idea that the stability of a society logically or factually depends on that class of religious beliefs which find pornogaphy obnoxious. Cf. Rex v. Curl, 93 Eng. Rep. 849 (K.B. 1727); P. Sorokin, The AMERICAN Sex Revolution (1956). Whatever may have been the plausibility of this view when morality was closely identified with theological premises, $c f$. note 114 supra, as an abstract argument it fails to have even superficial plausibility today. See H.L.A. HART, supra note 252; Hart, Social Solidarity and the Enforcement of Morals, 35 U. CHI. L. Rev. 1 (1967).

${ }^{250}$ E.g., the claim of Charles H. Keating, Jr., that it suffices to condemn pornography that it is against God's law. Keating, Statement, in REPORT, supra note 285, at 511, 515, 547.

${ }^{251}$ For such an argument, see H. GARDINER, supra note 41 , at 564-68. Gardiner acknowledges the principle that freedom can only be limited to advance freedom, but acknowledges higher freedoms involving special Catholic notions of sexual function. It 
free speech. To the extent that the Court's acquiescence in general prohibitions of pornography depends solely on such perceptions, it violates the fundamental moral rationale of the free speech and free press clause of the first amendment, and raises serious independent constitutional questions under the establishment of religion clause. ${ }^{252}$

Finally, Justice Burger argues that just as there is no conclusive evidence to support many laws, such as antitrust, securities regulation, and educational support laws, which have been held to be constitutionally justifiable, so the absence of evidence to support the obscenity laws cannot be used to attack their constitutionality. ${ }^{253}$ This argument confuses the lack of conclusive evidence with the lack of any evidence whatsoever. There is certainly evidence of a general theoretical and factual kind for the laws and institutions that Burger cites; there is no comparable evidence regarding the effects of obscenity. Burger's argument, if accepted, invites acquiescence in the most intractable prejudices, dismissing all evidence as irrelevant. It undermines the whole idea of rationality in legislation, substituting a notion of tradition that is a mask for ignorance and intolerance. The invalidity of this argument is even more extreme in the light of the values underlying the first amendment. Because the principle of equal liberty is fundamental to a moral theory of society, a higher burden of proof than is required in ordinary economic legislation is surely appropriate to justify legislation restricting that liberty. ${ }^{254}$ Yet, the Court allows the abridgement of equal liberty in the absence of any substantial evidence and on the basis of appeals to majority attitudes-precisely what the first amendment forbids.

\section{CONCLUSIONS}

A constitution both reflects and establishes the moral order of a society. Consequently, there is an intellectual need to harness

does not, of course, follow from the application of such a principle to himself that a Catholic necessarily applies it to other groups who do not share the religious perceptions underlying the condemnation. For an example of such a Catholic view, see Murray, Literature and Censorship, in The First Freedom 215 (R. Downs ed. 1960).

For a Catholic attempt to present empirical evidence, see M. Lorang, Burning IcE: The Moral and Emotional Effects of Reading (1968). $C f$. P. Johnson, On Iniquity (1967); F. Wertham, Seduction of the InNocent (1953). In general, Johnson and Wertham patently confuse causation and correlation.

252 See Epperson v. Arkansas, 393 U.S. 97 (1968); W. BARNETr, supra note 199, at 74-93; Henkin, supra note 148.

${ }^{253} 413$ U.S. at $60-63$.

${ }^{254}$ Of course, the Court by refusing to include obscenity in the class of expression protected by the first amendment, avoids the necessity of applying the strict evidentiary 
moral theory to constitutional theory. This Article has tried to show how a moral and philosophical theory of free expression fundamentally clarifies the problem of constitutional adjudication of the first amendment. On the view presented here, recent obscenity decisions, Miller and Paris Adult Theatre, are based on defective moral and legal analysis, wholly failing to explain why first amendment protection is not extended to the obscene. The Court could not have reached these decisions had it given precise thought to the nature of the obscene and the force of the moral theory behind the constitutional guarantees of free expression.

Obviously, this Article has not established a complete moral theory of the first amendment. The casuistry presented is far too sketchy. But the account, as a kind of preliminary sketch, suggests that some such theory, unifying intellectual principle with practical application, is possible. That moral and philosophical analysis can be a powerful force in understanding evolving legal ideas should be wholly unsurprising. ${ }^{255}$ If morals are the spirit of the law, careful moral analysis will inevitably bare the law's deepest intentions.

test normally applied to restrictions on protected forms of speech. See, e.g., Yates v. United States, 354 U.S. 298 (1957).

${ }^{253}$ In addition to the moral theory here employed, a related moral theory which may clarify legal ideas is that of R.M. Hare. See, R.M. HARE, FreEdom AND REASON (1963). My contrary remarks in Richards, supra note 2, at $71 \mathrm{n} .159$ were ill-considered, and I withdraw them with apologies to Professor Hare. Indeed, Professor Hare's theory may be understood as a kind of application of the contractarian theory here employed. For a discussion of the relation of the views, see B. BARRY, THE LIBERAL THEORY OF JUSTICE 12-13 (1973); D.A.J. Richards, supra note 15, at 83-85; Hare, Rules of War and Moral Reasoning, 1 Philos. \& Pub. Affairs 166, 167-71 (1972). 